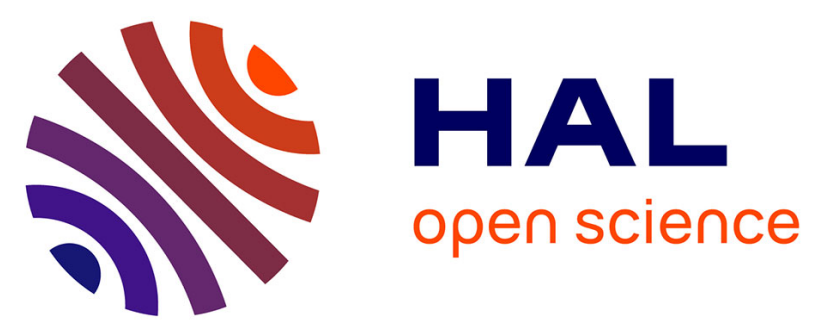

\title{
Erosion around a large-scale topographic high in a semi-arid sedimentary basin: Interactions between fluvial erosion, aeolian erosion and aeolian transport
}

\author{
Marc Jolivet, Regis Braucher, D. Dovchintseren, S. Hocquet, J.-M. Schmitt
}

\section{- To cite this version:}

Marc Jolivet, Regis Braucher, D. Dovchintseren, S. Hocquet, J.-M. Schmitt. Erosion around a large-scale topographic high in a semi-arid sedimentary basin: Interactions between fluvial erosion, aeolian erosion and aeolian transport. Geomorphology, 2021, 386, pp.107747. 10.1016/j.geomorph.2021.107747 . insu-03203903

\section{HAL Id: insu-03203903 \\ https://hal-insu.archives-ouvertes.fr/insu-03203903}

Submitted on 21 Apr 2021

HAL is a multi-disciplinary open access archive for the deposit and dissemination of scientific research documents, whether they are published or not. The documents may come from teaching and research institutions in France or abroad, or from public or private research centers.
L'archive ouverte pluridisciplinaire HAL, est destinée au dépôt et à la diffusion de documents scientifiques de niveau recherche, publiés ou non, émanant des établissements d'enseignement et de recherche français ou étrangers, des laboratoires publics ou privés. 


\section{Journal Pre-proof}

Erosion around a large-scale topographic high in a semi-arid sedimentary basin: Interactions between fluvial erosion, aeolian erosion and aeolian transport

M. Jolivet, R. Braucher, D. Dovchintseren, S. Hocquet, J.-M. Schmitt, ASTER Team

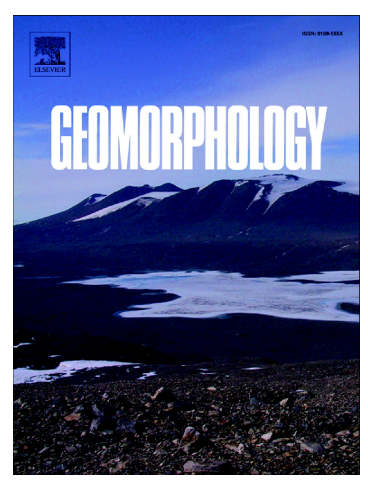

PII: $\quad$ S0169-555X(21)00155-0

DOI: $\quad$ https://doi.org/10.1016/j.geomorph.2021.107747

Reference: $\quad$ GEOMOR 107747

To appear in: $\quad$ Geomorphology

Received date: $\quad 8$ January 2021

Revised date: $\quad 1$ April 2021

Accepted date: $\quad 12$ April 2021

Please cite this article as: M. Jolivet, R. Braucher, D. Dovchintseren, et al., Erosion around a large-scale topographic high in a semi-arid sedimentary basin: Interactions between fluvial erosion, aeolian erosion and aeolian transport, Geomorphology (2021), https://doi.org/10.1016/j.geomorph.2021.107747

This is a PDF file of an article that has undergone enhancements after acceptance, such as the addition of a cover page and metadata, and formatting for readability, but it is not yet the definitive version of record. This version will undergo additional copyediting, typesetting and review before it is published in its final form, but we are providing this version to give early visibility of the article. Please note that, during the production process, errors may be discovered which could affect the content, and all legal disclaimers that apply to the journal pertain.

(C) 2021 Elsevier B.V. All rights reserved. 


\title{
Erosion around a large-scale topographic high in a semi-arid sedimentary basin: Interactions between fluvial erosion, aeolian erosion and aeolian transport.
}

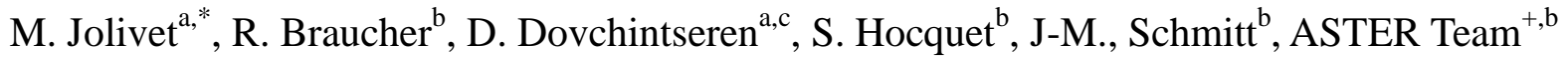 \\ ${ }^{a}$ Univ Rennes, CNRS, Géosciences Rennes, UMR6118, CNRS - F-35000 Rennes, France \\ ${ }^{\mathrm{b}}$ Aix-Marseille Univ, CNRS-IRD-Collège de France-INRAE, UMR34 CEREGE, Technopôle de \\ l’Environnement Arbois et Méditerranée, BP80 13545 Aix-en-Provence, France \\ ${ }^{\mathrm{c}}$ Orano Mining, 1, place J. Millier, 92400 Courbevois, France
}

+ ASTER Team: G. Aumaître, D. Bourlès, K. Keddadouche.

\begin{abstract}
Large-scale aeolian erosion features such as pans usual'y ' 'evelop upon a relatively homogeneous erodible sedimentary rock substratum and show simץ'e nncave morphologies. However, some erosional depressions in semi-arid to arid settings del elop in more complex geological contexts, associating sedimentary basins and outcrop it nn-erodible basement. In semi-arid basins, the geomorphic evolution is controlled by intc lay between the processes of fluvial erosion and deposition (especially of the finer sedit. ant fraction in ephemeral lakes) and the processes of aeolian erosion and deflation. The occl. $\mathrm{r} \_\mathrm{n} \_\mathrm{e}$ of non-erodible basement outcrops within a region of overall deflation complicates drain - ge systems and wind-flow patterns. Both are liable to evolve rapidly through time and their in ractions remain poorly understood. In this study, we use a detailed geomorphological anaı, sir, including mapping of the aeolian sand-motion direction within the $16,300 \mathrm{~km}^{2}$ Tsaga $\mathrm{L}^{1 \mathrm{~s}}$ 'epression (Gobi Desert, Mongolia) as well as in situ-produced cosmogenic ${ }^{10} \mathrm{Be}$ and ${ }^{26} \mathrm{~A} 1 \mathrm{r}$ ased quantitative constraints, to propose a conceptual model for the morphologic evolution of geologically complex semi-arid basins. Based on theoretical studies of wind-flow patterns around obstacles, we demonstrate that the occurrence of erosion-resistant basement highs inside the basin induces the localization of preferential deflation zones and aeolian and fluvial carving of large-scale relief. The enhanced deflation zones form sub-depocenters controlling local drainage systems that mobilize clastic material and transport it to the deflation zone. These river systems are frequently captured by neighboring streams, which creates unstable conditions of erosion and deposition. Such rapid modifications of the topography through time affect the hydrogeologic structure of the basin and may impact potential sediment-hosted mineral deposits.
\end{abstract}




\section{Keywords}

Aeolian erosion; Fluvial-aeolian interaction; Aeolian geomorphology; Cosmogenic radionuclides; Gobi desert

\section{Introduction}

Aeolian erosion generates a number of geomorphic structures whose sizes span from centimeter scale ventifacts to meter- to tens of kilometers-scale yardangs, anc ${ }^{\dagger} \mathrm{o}$ blowouts and pans that can be hundreds of kilometers in diameter (Blackwelder, 1934; Goud e, :989; Goudie and Wells, 1995; Hesp, 2002; Laity, 2011). Pans form relatively flat, closed de src: sions that may cover thousands of square kilometers, such as the Etosha pan in Namibia (Нір - пdока, 2005; Miller et al., 2010). Those that do not have a karstic origin (Albritton et al., 190(1) us dally form upon sedimentary rocks in wide flat areas mostly through a combination of wind deflation, salt weathering and, during wetter periods, lacustrine processes (waves) (Goudie, 1.5.1. Wormald et al., 2003). In the absence of erosion-resistant obstacles, pans have a ror ade 1 to oval shape due to the relatively homogeneous mechanical resistance to erosion of the substraı. $n$ (Goudie, 1991; Goudie and Wells, 1995). Indeed, wind erosion associates deflation (rem?vai of loose particles by the wind) and wind abrasion (removal of attached particles thror $\mathrm{rh}$ mpacts of transported grains). Unless the substratum is poorly consolidated, the initial $\mathrm{m}$ sbi ${ }^{*}$ zation of particles is generally caused by fluvial erosion or weathering. Wind abrasion (her 'fter referred as abrasion) is generally only bringing a minor contribution to the material ar iliable to wind-transport (Aref et al., 2002; Laity, 2011). Deflation and abrasion are mainly c. nuulled by the wind velocity (Bagnold, 1941; Iversen et al., 1990). In flat, obstacle-free regions, we wind velocity and direction can be considered as constant over the whole surface, leading to the rounded form of large blowouts or pans that can develop from an initial surface disturbance such as fault scarps, river channels or dry lakes (Goudie, 1991; Wormald et al., 2003; Barchyn and Hugenholtz, 2013). When obstacles are present, the wind flow becomes more complex as eddies, reversed flow regions, wind-acceleration zones and wind channels start to develop (Hunt et al., 1978; Laity, 1987; Ruszkiczay-Rüdiger et al., 2007, 2009, 2011; Sebe et al., 2011). This in turns leads to the localization of preferential erosion and sand deposition zones, increasing the complexity of the topography. 
Using analog (Castro and Robins, 1977; Hunt et al., 1978; Iversen et al., 1990; Tominaga et al., 2018) and numerical modeling (Badr and Harion, 2005, 2007; Wakes et al., 2010; Jackson et al., 2013; Tominaga et al., 2018; Liu et al., 2019), numerous studies have addressed the effects of obstacles or topography on the wind flow pattern. These studies mainly addressed the localization of preferential deflation zones or wind shadows. However, although in many natural dryland settings, fluvial processes interact with the aeolian sediment-transport and erosion processes, these studies only deal with wind dynamics and never take into account the role of fluvial erosion in creating loose particles, transporting them outside or inside the system or segregating them by size. Furthermore, when applied to natural cases, many of these studies deal with simple, small-scale topographies such as dune fields or small hills. Another series of studies based on satellite images and completely disconnected from the fluid dynamics approach. des ribe the interactions between aeolian dunes and large rivers (Krapf et al., 2003; Liu and Conlı ar $\boldsymbol{r}_{\lrcorner}$, 2015, 2017; Al-Masrahy and Mountney, 2015), investigate the role of fine-grained rive a nr sits in providing material to dune fields (Maroulis et al., 2007) or, on the contrary the rews $\_$ki ' $\mathrm{g}$ of fine-grained aeolian loess deposits by rivers (Williams, 2015). However, these studies do no. consider the erosion mechanism at the source of the detrital material and little qua tiaive information is provided (erosion or sedimentation rates). Finally, several field-b.w ${ }^{+}{ }^{+}$Ildies have addressed the exchange of sediment particles between fluvial and aeolian systen depending on the sediment availability in rivers or dunes and the vegetation cover (Mush eı १l., 1996; Bullard and Livingstone, 2002; Draut, 2012; Sankey et al., 2018a) or river flow (Sar'ź y i al., 2018b; Santos et al., 2019).

A key question that therefore rem iin. is how to most effectively quantify how fluvial and aeolian processes interact in driving the 1 ng-term topographic expression of large-scale obstacles. We will address this question throur, in ' yeomorphological study of a series of small basins separated by basement highs in the Got: tesert of Mongolia. The endoreic setting of this region prevents changes in boundary conditions to ine studied system, especially the capture and generally associated rapid modification of the fluvial system by an adjacent drainage area. Furthermore, the Gobi Desert has an arid climate with intense aeolian activity and vegetation is limited to grass and small saxaul bushes (Haloxylon sp.). Such a setting, including a complex drainage system, active aeolian processes, the near absence of vegetation and a marked lithological substratum pattern, is ideal to study the interaction between aeolian and fluvial processes. The aim of the work described below is to propose a conceptual model of landscape evolution resulting from aeolian and fluvial interactions around a large natural obstacle within a sedimentary basin. 


\section{Description of the study area and methodology}

A first estimate of the wind pattern over the study area was obtained using the European Centre for Medium-Range Weather Forecast Re-Analysis (ERA-Interim) model that provides $10 \mathrm{~m}$ above ground wind velocity and direction data. In order to investigate the interplay between fluvial erosion and deflation, we mapped the drainage network with special focus on positioning local base levels. We then mapped the sand-transport directions as reflecting the wind-flow pattern at ground level and correlated this pattern with the surface morphology (including the drainage system) to detect potential preferential deflation zones. We also measured in situ-produced concentrations of the ${ }^{10} \mathrm{Be}$ and ${ }^{26} \mathrm{Al}$ cosmogenic nuclides to quantify the erosion rates over the basin and to better understand the effect of the basement highs on the large-scale erocion ,attern.

\subsection{Geomorphology and hydrology of the Tsagaan Els der it ion}

The Tsagaan Els depression in SE Mongolia is a $\sim 16,3110 \mathrm{k} \mathrm{\textrm {n } ^ { 2 }}$ endorheic depression subdivided by the North Zuunbayan fault zone into the Unegt sub-hasin to he north and the Zuunbayan sub-basin to the south (Figure 1) (Graham et al., 2001; C'17'rd et al., 2019). The entire depression is undergoing active erosion and surface lowe ing Thu lowest point of the depression is $700 \mathrm{~m}$ above sea level (a.s.1.) and is situated within the eası rn part of the Zuunbayan sub-basin with a second low zone (750 $\mathrm{m}$ a.s.1.) in the SW part $\mathrm{o}^{\mathrm{f}}$ the Jnegt sub-basin (Figure 1). The basin floor consists of sedimentary bedrock covered by a thin l v r of gravel pavement and aeolian dunes in some places (see description below). The com le drainage system of the depression is composed of a fractallike series of sub-systems associand with local base levels filled by ephemeral lakes in which water is only present for very sho $r$ arıds of time, generally following heavy rain events. This includes the effective base level or the depression situated in the NE part of the Zuunbayan sub-basin that forms a large playa (Figuı 1). Some of those sub-systems are associated with large rivers, all of which are ephemeral or seasonal (no baseflow), due to the arid climate but many are formed by a series of small, poorly organized drains showing sharp knickpoints implying rapid incision due to base-level drop (Whipple and Tucker, 1999; Crosby and Whipple, 2006). The present-day Tsagaan Els depression is superimposed on a complex pattern of Upper Jurassic - Lower Cretaceous grabens and half-grabens sealed by Late Cretaceous to Cenozoic post-rift alluvial, lacustrine and aeolian deposits including carbonate paleosols (Johnson et al., 2001; Graham et al., 2001; Johnson, 2004; Webb and Johnson, 2006; Daoudene et al., 2017). Thin Paleogene to Neogene strata contain numerous aeolian dune deposits and calcisols, both indicating a long-lasting arid to semi-arid 
climate (Currie and Eberth, 1993; Caves et al., 2014; Naugolnykh, 2016). The Mesozoic basins are separated by or contain fault-limited basement highs composed of Proterozoic to Paleozoic crystalline rocks (Webb and Johnson, 2006; Daoudene et al., 2017).

In the center of the Tsagaan Els depression, the c.a. $55 \mathrm{~km}$ long, $20 \mathrm{~km}$ wide Tavan Har basement high culminates around $975 \mathrm{~m}$ a.s.l. and $250 \mathrm{~m}$ above the lowest point of the depression (Figures 2 and 3a). Similarly, to all the exposed basement highs in the Tsagaan Els region, the Tavan Har hill is characterized by a flat summit corresponding to a regional erosional planation paleosurface (Figure $3 \mathrm{a}$ and d) (Jolivet et al., 2007; Vassallo et al., 2007). Large areas of the plateau are devoid of sediments, except for some Quaternary sand sheets, some of them filling small canyons (Figure 3d). On the slopes that are not covered by Mesozoic sediments, col'vial forms a few centimeter- to decimeter-thick layer of sharp edged, unsorted, in-situ produced 'sas ment blocks and gravels mixed with aeolian sand.

The northern edge of the Tavan Har horst is limited by the 1 'E-SW striking North Zuunbayan fault zone (Figure 3b). Cretaceous strata are exposed along he sorthern margin of the Tavan Har hill, with bedding largely sequent to the surface morphciv, y (Figure 3b), itself characterized by a northfacing conical structure linking the summit of $t^{1} \mathrm{e}$ basement high to the lowest part of the Unegt sub-basin (Figures 2 and 3b). This struct re eroded into the Cretaceous series corresponds to a bedrock pediment supporting active mater-hign aeolian dunes, decimeter-thick sand sheets and centimeter-thick layers of strongly $\mathrm{W} \cdot \mathrm{d}$-polished gravels originating from the underlying Cretaceous deposits (Figure 3e and sinplementary Figure 1). The present-day depocenter of the Unegt sub-basin is occupied by a eries of ephemeral lakes (Belnap and Ludwig, 2001) distributed along an arcuate line parallel $t \backslash$ the Sront of the Tavan Har conical structure (Figure 2). To the north, the topography rises again $\mathrm{n}$ to the summit of the Mandakh-Saykhanduklaan basement ridge which limits the northern part of th، Tsagaan Els depression (Figure 1).

To the south, the Tavan Har basement high is limited by a series of NE-SW striking Early Cretaceous normal faults (Figures 2 and 3c). The relief between the metamorphic basement and the Zuunbayan sub-basin is generally steep, corresponding to differential erosion of the fault planes. Although the depocenter of the Zuunbayan sub-basin is situated some $35 \mathrm{~km} \mathrm{NE}$ of the eastern reach of the Tavan Har hill, two secondary depressions form local depocenters immediately NE and SW of the basement high (Figures 1 and 2). The NE depression is largely elliptical, with a lowest point at $760 \mathrm{~m}$, about $150 \mathrm{~m}$ below the mean altitude of the eastern part of the Tavan Har plateau. The bottom of the depression corresponds to an ephemeral lake. The drainage system associated with the depression is mainly composed of two rivers, one flowing from the SW along the edge of 
the Tavan Har basement high, the other coming from the south with a source in the Totoshan basement ridge (Figure 2). This closed depression contains the only exposure of lower Cretaceous strata in the western part of the Zuunbayan sub-basin. The SW depression is elliptical, with a long axis parallel to the edge of the basement high. The lowest part of the depression is again formed by an ephemeral lake at an altitude of $760 \mathrm{~m}$. However, unlike in the NE depression, only Late Cretaceous strata are exposed, suggesting a lower amount of denudation. The drainage system associated with the depression is formed by a single river flowing from the southern part of the Tavan Har basement high (Figure 2).

The Tsagaan Els depression contains several active dune fields (Figures 4 and 5). They range in size from 100 to $1000 \mathrm{~km}^{2}$, contain meter- to decameter-thick accul "ilations of sand and show well developed parabolic and transverse dunes (Figure 5a). Othe's a e only sand sheets of a few centimeters to decimeters thick with few parabolic du es. some of the dune fields are geographically closely associated with water saturated are s such as ephemeral lakes, major rivers or springs (Mountney and Russell, 2009). For both pa ${ }^{-1}$ bol $c$ and transverse dunes, the crest lines are sub-perpendicular to the sand-transport direction (Mountney, 2006; Courrech du Pont et al., 2014; Gao et al., 2015). In some specific places s a' a, downwind of ephemeral lakes that provide fine-grained unconsolidated material, raked int ar cunes are present with their long axis parallel to the sand transport direction (Figure 5b) (Mounı`ey, 2006; Courrech du Pont et al., 2014). However, most of the depression is characterized hy : lag deposit forming a reg-type ground (the term reg refers to a rocky desert with a limited $a m$ w $n$ of sand) usually represented by a thin, one-grain thick layer of pebbles or cobbles of var ab: lithology including metamorphic basement, pure quartz and sediment (Figure 3a). On the reg, and accumulation only occurs as sand shadows or coppice dunes behind plants (Figure 5c). Tin disection of sand transport then corresponds to the direction of the long axis of the sand shaa ' $v$. I he size of these small structures varies, depending on the height and width of the associated buviles and, although the smallest ones generally indicate the direction of sand transport during the last strong-wind episode, we consider the largest ones, sometimes up to a meter in height, to be more perennial features representative of the mean direction of wind-blown sediment transport.

Finally, the Tsagaan Els depression hosts shallow aquifers mainly in the Upper Cretaceous formations and Quaternary deposits (Grizard et al., 2019). Grizard et al. (2019) demonstrated that the aquifers in the Upper Cretaceous series of the Zuunbayan sub-basin are controlled by the main central depression, with the water flowing from the edges of the sub-basin and discharging via subsurface evaporation in the central playa (Figure 4). In the Unegt sub-basin, the water in the 
aquifer flows eastward toward a series of springs situated east of the Tavan Har basement high, along the North Zuunbayan fault (Figures 2 and 4).

\subsection{Climate of the Tsagaan Els depression}

Climate data were obtained using the Climate Data Online catalog of the U.S. National Oceanic and Atmospheric Administration for two weather stations: Sainshand (N44.900 / E110.117 ${ }^{\circ}$, with data collected every 3 hours from August 1956 to May 2017) and Bayan Dobo Suma (N44.567 / E107.183 ${ }^{\circ}$, with data collected every 3 hours from December 1973 to May 2017) in the NE and NW of the depression respectively (Figures 1 and 6). At both st tions, the main wind direction is from the NW, with a limited spread between WNW and $\mathrm{N}, \ldots$ a wind speed value generally between 10 and $35 \mathrm{~m} \cdot \mathrm{s}^{-1}$ (Figure 6). The wind direction durine, ${ }^{+} u_{n+1}$ events is similar to the overall wind direction, although a more westward component is obs..ved. The temperature distribution shows a wide amplitude between about $-20^{\circ} \mathrm{C}$ in winter anc about $+20^{\circ} \mathrm{C}$ in summer with extremes below $-40^{\circ} \mathrm{C}$ and above $40^{\circ} \mathrm{C}$. Precipitation data are c.lly ivailable for the Sainshand station and show that most precipitation occurs between June $1>$ A gust with a mean annual amount of only 59 $\mathrm{mm}$ over the considered period and some out $\mathrm{te} s \mathrm{u}_{\mathrm{r}}$ to $70 \mathrm{~mm}$ per month generally due to storms.

\subsection{Methods for data acquisition}

\subsubsection{Description of the wind patterns}

The wind pattern (speed and dis $r t_{1}$ ) in the Tsagaan Els depression was first investigated using the ERA-Interim project metons:'ogical model which provides estimates of the wind speed and direction at altitudes of $\mathrm{l}_{\mathrm{1}} \cdots 100 \mathrm{~m}$ above ground level (Simmons et al., 2007; Dee et al., 2011). However, this model has a $\mathbf{~}^{\prime \prime} \mathrm{km}$ grid resolution and does not account for wind perturbations due to local, small-scale topographic structures. To get a more accurate evaluation of the wind mean directions at ground level, we used field and satellite (see example study in Yao et al., 2007) measurements of the direction of propagation of the dunes and sand shadow features described above. This approach does not provide information about the wind speed. Direction values (measured clockwise from north) were gridded and interpolated using the "surface" calculation routine of the GMT Software (Smith and Wessel, 1990) to derive sand transport maps at ground level that we interpret as a proxy for wind direction. Note that the density of data is largely controlled by the occurrence of sand in the various regions of the basin which has a direct influence on the confidence level of the interpolation. 


\subsubsection{Cosmogenic nuclide dating methods}

\subsubsection{Sampling strategy}

Cosmogenic nuclide analysis was used to derive the exposure age and erosion rates of the various surfaces in the depression. Pure quartz to quartz-rich samples were collected from surface lag deposits, sedimentary rocks or crystalline basement throughout the basin and especially around the eastern termination of the Tavan Har structure (Figures 2 and 4, Supplementary Figure 1 and Supplementary Table 1). Sampling sites were selected on flat surfaces, away from fluvial courses to prevent river-related slope diffusion that could locally increase the erosion rates. All sampled morphologies are erosion surfaces as lag deposit samples were collected from the reg-type soil described above, away from material that could have been brought $b$; sheet-flood deposits. Except for sample M-61 in the main depression, no sample was collerte $\mathrm{C}_{\mathrm{fr}}^{\mathrm{Jm}}$ ephemeral lakes surfaces to prevent shading by water of fine-grained deposits linked to I $\mathrm{nr}$ ding. The local topography being largely low-relief sample shading by obstacles is limited (so supplementary Table 1).

The samples were either single quartz cobbles about $10 \mathrm{~m}$ in diameter, sets of about 50 quartz pebbles about $1 \mathrm{~cm}$ in diameter (quartz cobbles or ${ }_{i}^{\prime} \mathrm{e}^{\prime}, \mathrm{b}$ 'es found loose on the surface or as particles in sedimentary rocks are generally derived f. $\mathrm{m}$ soded basement metamorphic veins) or granite and quartz vein chunks. This sampling wa complemented by sampling of quartz-rich coarsegrained sedimentary rocks in three drillı. s sites (see below for detailed sedimentary logs of the three sections). Two of the sites wer , it ıted on the Bayanshire plateau, a preserved, isolated morphological surface in the Unegt Subuasin (Figure 2) possibly representing a remnant of the preincision topography of the basin the third profile was excavated into the main depression being possibly representative of the $\mathrm{n}_{\mathrm{n}} \mathrm{ns}$, actively eroding part of the basin. Details on samples location and cosmogenic nuclides $o^{`}{ }^{\text {ter }}$ is are available in Supplementary Table 1.

\subsubsection{Dating methods}

Sample preparation and measurement procedure follow the usual approach and are fully described in the supplementary file "Cosmogenic nuclides analysis" . Erosion rates and exposure ages were calculated using the classical equation of the nuclides production:

$$
\begin{aligned}
& N(x, \varepsilon, t)=\frac{P_{\text {neut. }} \mathrm{e}^{\left(-x \rho / \Lambda_{\text {neut. }} .\right)}}{\frac{\varepsilon \rho}{\Lambda_{\text {neut. }}}+\lambda}\left[1-\mathrm{e}^{-t\left(\varepsilon \rho / \Lambda_{\text {neut. }}+\lambda\right)}\right]+\frac{P_{\text {stop. }} \mathrm{e}^{\left(-x \rho / \Lambda_{\text {stop }} .\right)}}{\frac{\varepsilon \rho}{\Lambda_{\text {stop. }}}+\lambda}\left[1-\mathrm{e}^{-t\left(\varepsilon \rho / \Lambda_{\text {stop. }}+\lambda\right)}\right] \\
& +\frac{P_{\text {fast }} \mathrm{e}^{\left(-x \rho / \Lambda_{\text {fast }}\right)}}{\frac{\varepsilon \rho}{\Lambda_{\text {fast }}}+\lambda}\left[1-\mathrm{e}^{-t\left(\varepsilon \rho / \Lambda_{\text {fast }}+\lambda\right)}\right] \\
& +\mathrm{N}(0, \text { paleo } \varepsilon, \infty) \cdot \mathrm{e}^{(-\lambda \cdot t)} \text { Equation } 1 .
\end{aligned}
$$


A SLHL spallation production of $4.02 \pm 0.33$ atoms $\mathrm{g}^{-1} \mathrm{a}^{-1}$ (Borchers et al., 2016) was used and scaled using Stone polynomial (Stone 2000) and Cosmocalc Excel add-in (Vermeesch, 2007). Muon contributions of Braucher et al. (2011) were applied. The ${ }^{26} \mathrm{Al} /{ }^{10} \mathrm{Be}$ production ratio induced by the standardization used at ASTER (SM-Al-11/07KNSTD) is 6.61 \pm 0.50 (Rixhon et al., 2011).

From the measurement of the concentration of two cosmogenic nuclides $\left({ }^{10} \mathrm{Be}\right.$ and $\left.{ }^{26} \mathrm{Al}\right)$ in a single sample, the three unknowns (paleo-erosion rate: paleo $\varepsilon$, erosion rate: $\varepsilon$ and exposure age: $\mathrm{t}$ ) from Equation 1 (see Supplementary file "Cosmogenic nuclides analysis" for details) cannot be determined simultaneously since the equations used for each of the cosmogenic nuclides contain the same unknowns. Therefore, two options are possible (Supplemen 'ry Table 2). First, considering no inheritance (simple exposure history), where using Equat on to allow modeling both the exposure age (t) and the erosion rate $(\varepsilon)$. Following this appr ach, concentrations increase with time until they reach a constant value when the gains by produ tion equal losses by radioactive decay and erosion. The time needed to reach this plateau valu th 2 integration time, directly depends on the erosion rate and marks the theoretical limit of th - tating method: it is impossible to date beyond this integration time. Secondly, considering a con ${ }_{\iota_{\mathrm{r}}}$.ex exposure history where "burial", paleoerosion (paleos) and exposure age (t) can $b$ de ermined assuming no production after deposition. In that case, the resulting age will be mini num. As discussed in section 4.2, this "burial" can in fact only be virtual and result from a $\operatorname{ch} n_{3}, 1, n$ the erosion rate which induces a variation in the

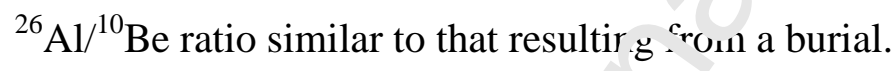

These two options will allow tacisting of the denudation rates and exposure ages. All outputs presented in this study consider ${ }^{2} \mathrm{ch}{ }^{10} \mathrm{Be}$ and ${ }^{26} \mathrm{Al}$ measurements together. However, to provide a full analysis of the dan li a classical maximum erosion rates (considering infinite time) and minimum exposure age (no erosion) considering one nuclide have been presented in Supplementary Table 2 as well as the same approach of maximum erosion rate considering both nuclides. The latter option, considering maximum erosion rates, results in more difficulties in reproducing the data.

Finally, because both ${ }^{10} \mathrm{Be}$ and ${ }^{26} \mathrm{Al}$ nuclides are produced in the same mineral and thus have undergone the same exposure history since they were emplaced in the sedimentary rock, it is possible to analyze multiple samples from a vertical profile to determine more than two unknowns. In that case the paleo-erosion (paleos) that affected each profile sample before its burial, and both the erosion rate $(\varepsilon)$ and the exposure time since the deposition event $(\mathrm{t})$ can be determined with a 
minimum of two samples. For all samples from a given depth profile, these two latter unknowns are identical.

\section{Results}

\subsection{Wind pattern from ERA-Interim data $(10 \mathrm{~m})$}

Mean wind pattern (direction and speed at an altitude of $10 \mathrm{~m}$ above the ground) have been calculated for 3 different months based on the ERA-Interim model (Figure 7). In general, the calculated wind speed is maximum in the central part of the Unegt Basin, immediately in front of the Tavan Har structure and decreases on the lee side of the basement high in the Zuunbayan Basin before increasing again on reaching the Totoshan Ridge to the sc 'th. As expected, streamlines show a marked deflection produced by the Tavan Har topograph ${ }_{0}$. Tl e wind blowing from the north in the Unegt Basin (a direction mainly consistent with the net orological observations presented above) is either simply deflected toward the SE (see the $I_{l_{1}}-2016$ example on Figure 7) or, more generally, forms vortices on the lee side of the NE ana $\mathrm{SU}$ terminations of the Tavan Har massif and flow reversal develop in the Zuunbayan Basin $r_{1}$.ting a complex wind pattern.

As dust and sandstorms associated with strr $\mu_{c}$ winds are known to be a major factor influencing soil erosion and sand movement in the soutı rn Gobi region (Middleton, 1991; Natsagdorj, 2003; Kapp et al., 2015), we also calculated winc pattern maps (wind at an altitude of $10 \mathrm{~m}$ above ground) for three days corresponding to la:ge storms (storm days have been selected using the meteorological data available for the Sainshand Station as described above). Although the compilation of strong wind data l. gistered at Sainshand weather station indicate NW to WNW winds (Figure 6), the three ER A In .erim derived maps show mostly a W to WNW wind direction on the western side of the 7 ag an Els depression, rotating NE in the eastern part of the basin. Except

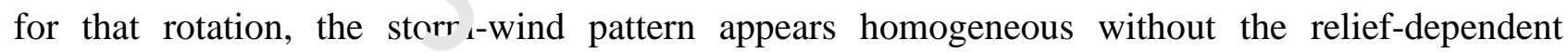
disturbances observed in the monthly averages. Finally, the modeled storm wind direction is poorly to not compatible with the direction of propagation of the major dune fields in the depression (see below).

\subsection{Aeolian sand transport around the Tavan Har structure}

Measurements of the sand transport direction have been interpolated to produce a large scale map of sand motion within the Tsagaan Els depression (Figure 8). It should be noted that this map largely relies on the density of data and most of them were obtained in the close vicinity of the Tavan Har 
structure. In most of the Unegt sub-basin, the transport direction is NW to SE, corresponding to the measured mean wind direction at Sainshand and Bayan Dobo Suma stations (Figure 6) and oblique compared to that predicted by the ERA-Interim model (Figure 7). In the Zuunbayan sub-basin, the wind direction changes towards close to westerly before switching again towards a more WNW direction on the Totoshan ridge to the south. This last direction corresponds to that of a major dune field separating the Zuunbayan sub-basin from the Erdene valley to the East (Figures 1 and 4). West of the Zuunbayan sub-basin, the transport direction is largely W-E, marked again by a large dune field. Again, in these two locations, the measured sand transport directions are oblique to the wind direction predicted by the ERA-Interim model although not entirely incoherent. Figure $8 \mathrm{~b}$ is a closer view of the interpolated sand transport directions around the Tavan Har structure. As indicated above, the transport direction is largely constant towards the SE in the Unegt sub-basin as well as on the conical structure north of the basement high. Tow $\cdot d r$ the NE, where the slope of the cone decreases, the transport direction changes towards a $1 \mathrm{e}^{-{ }^{-} \mathbf{l}_{\mathbf{v}}} \mathrm{W}$-E direction before establishing back to the SE away from the termination of the basem ill 'igh. On the southern side of the Tavan Har hill, the transport direction varies from NW-SE to $\mathrm{V}_{-\mathbf{L}}$ indicating a strong topographic control on wind direction. The topographic depression sou $\mathrm{b}$ of the NE termination of the basement high is

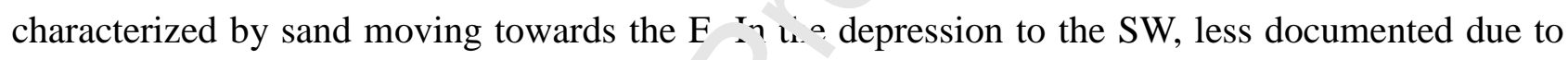
the near absence of sand (the ground is la: ely covered by a gravel to pebble pavement), the transport direction is WNW-ESE.

Based on those observations, it appears th th the large Mandakh-Saykhandulaan ridge north of the Tsagaan-Els depression has no or on: a minor effect on the wind direction in the Unegt sub-basin (this one remains consistent $\mathrm{W}_{\mathrm{\imath}} \mathrm{h}^{\mathrm{h}}$ ine regional wind direction). These winds probably have a katabatic component and in "ease in speed as flowing down into the basin. However, the measurements confirm tha. the Cavan Har basement high exerts a major control on the wind pattern inside the Zuunbayan sub-vasin.

\subsection{Erosion rates and chronology inferred from in situ-produced concentrations of the cosmogenic ${ }^{10} \mathrm{Be}$ and ${ }^{26} \mathrm{Al}$ nuclides}

\subsubsection{Surface samples}

The modeled erosion rates calculated from cosmogenic nuclides data as well as their Kernel density plot (Vermeesch 2012) are presented in Figure 9 while associated ages are reported in 
Supplementary Table 2. Note that the value implemented for a given sample in the Kernel density calculation (Figure 9b) has been selected considering the best fitting result from option 1 or option 2 . This best fit was determined using the highest probability of $\left.\chi^{2}=\left(\left(\mathrm{N}_{\text {measured }}-\mathrm{N}_{\text {modeled }}\right) / \sigma_{\text {measured }}\right)\right)$, $\sigma_{\text {measured }}$ being the uncertainty associated to the measured concentration $\left(\mathrm{N}_{\text {measured }}\right)$, determined for each calculation result (Supplementary Table 2). In most cases, the two-options yield similar longterm erosion rates ranging from 0 to $49.3 \mathrm{~m} / \mathrm{Ma}$. Ignoring this latter extreme value, the Kernel curve exhibits two maxima, one at $\sim 7 \mathrm{~m} / \mathrm{Ma}$, the second at $\sim 20 \mathrm{~m} / \mathrm{Ma}$. The two types of samples (multiple pebbles versus single cobble) lead to consistent results. However, the erosion rates of 7 surface samples are significantly different (the names of these samples are indicated on Figure 10). This may be due either to heterogeneity in the amalgamated samples or to a different exposure history that may involve partial burial of single cobbles. The heterogenait, refers here to the potential presence in the amalgamated sample of one or several pebhles * th anomalously high (or low)

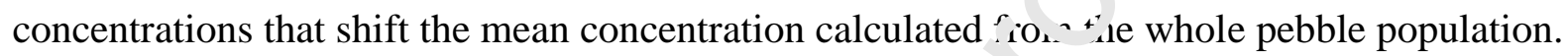

Samples from the Totoshan ridge, as well as from a small $b$ sement high above the southern edge of the Zuunbayan sub-basin, yield erosion rates betwe $x$ r 0 and $10 \mathrm{~m} / \mathrm{Ma}$ (Figure 4). Samples MN17-50 and MN17-53 yield erosion rates slightly is gh than $10 \mathrm{~m} / \mathrm{Ma}$, but they are situated on a sedimentary surface at the base of a $50 \mathrm{~m}$ his: cliff. The top of the cliff is affected by erosion rates lower than $5 \mathrm{~m} / \mathrm{Ma}$ (samples MN17-51 and MN17-52), indicating large variations at a small local scale. To the north of the study area, $c_{n}$ th $=$ large fan-terraces system that separates the MandakhSaykhandulaan ridge from the low st part of the depression in the Zuunbayan sub-basin, erosion rates vary from less than $5 \mathrm{~m} / \mathrm{Mc}$. up ${ }^{\dagger} \mathrm{o}$ nearly $20 \mathrm{~m} / \mathrm{Ma}$.

However, the most scattered resc ${ }^{11}$, were obtained around the Tavan Har structure. Samples MN171 and MN17-2 with eros: n atrs of $26.13 \pm 3.38 \mathrm{~m} / \mathrm{Ma}$ and $31.53 \pm 3.05 \mathrm{~m} / \mathrm{Ma}$, respectively, were collected from the top of a conglomerate ridge immediately north of the North Zuunbayan fault. This ridge forms the northern boundary of a depression (several hundred meters across and tens of meters deep) developing between the basement and the Cretaceous strata. Immediately to the north, samples MN17-3 to MN17-5 were collected along the slope of the conical structure. They yield higher erosion rates, increasing towards the top of the structure. Samples MN17-7 and MN17-8 were collected in the ephemeral lakes that form the local base level at the foot of the conical surface. They provided some of the highest erosion rates at around 20 to $25 \mathrm{~m} / \mathrm{Ma}$. South of the eastern termination of the Tavan Har basement, samples MN17-31 and MN17-32 were collected on the plateau forming the summit of the basement high. Sample MN17-31 is a quartz vein in the gneiss while sample MN17-32 is a surface quartz cobble. They lead to erosion rates of $6.24 \pm 3.24$ and 
$4.22 \pm 0.63 \mathrm{~m} / \mathrm{Ma}$, respectively, similar to those obtained on the Totoshan ridge. Sample MN17-34 was also collected on the southern edge of the plateau but on the edge of a small, $30 \mathrm{~m}$ large and 10 $\mathrm{m}$ deep canyon which might explain its higher erosion rate of $14.39 \pm 5.22$. Finally, on the southwestern edge of the main depression zone in the Zuunbayan sub-basin, sample MN17-61 records an intermediate erosion rate of $10.38 \pm 0.79 \mathrm{~m} / \mathrm{Ma}$.

Regarding the ages obtained through the two approaches (Supplementary Table 2), they significantly vary depending on the selected modeling option, unlike the erosion rates. In addition, considering the simple exposure model (one nuclide), the calculated ages may be considered as too old to be compatible with the calculated erosion rates. Indeed, the integration times (considering all particles involved i.e. neutrons and muons) range from $2 \mathrm{Ma}$ for $\mathrm{a}^{\urcorner}$erosion rate of $0 \mathrm{~m} / \mathrm{Ma}$ down to $\sim 30 \mathrm{ka}$ for a $\sim 50 \mathrm{~m} / \mathrm{Ma}$ erosion rate (the erosion range obtained in . his study), making them higher than those which theoretically cannot be exceeded.

Considering the paired ${ }^{10} \mathrm{Be}$ and ${ }^{26} \mathrm{Al}$, these offer the possik lity to have a perfect match between the modeled and measured concentrations because the tim cor sidered is not only the time needed to accumulate the nuclides but also the time needed for the prociaced nuclide to decay.

When both modeled options yield to the same $r \mathrm{rc} 1 \mathrm{rate}$, an agreement is also observed when looking at maximum erosion rates deduced iro n individual nuclides (see Supplementary Table 2). In that case a simple exposure history is to be $t_{a}{ }^{r}$ ored.

\subsubsection{Depth profiles}

The ${ }^{10} \mathrm{Be}$ and ${ }^{26} \mathrm{Al}$ concentrations wert measured along three depth profiles dug into the basin for this purpose (Figure 11 and S: vplt, nentary Table 1). Profiles P1 (samples MN17-10 to MN17-19) and P2 (samples MN17-3, to MN17-45) are situated on the Bayanshire plateau, an isolated, perched morphological surta e located immediately NE of the eastern termination of the Tavan Har structure. This erosion surface is cutting through the Upper Cretaceous Bayanshire deposits and displays two sub-surfaces: a low sub-surface to the $S$ in which profile P1 was sampled and a high sub-surface to the $\mathrm{N}$ in which profile $\mathrm{P} 2$ was sampled. Although no evidence of active deformation could be obtained from field investigation, the scarp separating the two sub-surfaces coincides with the mapped trace of the North Zuunbayan fault (Figure 11).

The low sub-surface (profile P1) is flat with only a few small dunes along its eastern edge and no evidence of river incision. It is paved by centimeter-size, moderately wind-polished pebbles of quartz and metamorphic rocks. The section exposed along the cliff at the southern edge of the subsurface suggests that the post-Cretaceous deposits are less than a meter thick. Indeed, the upper 
first $30 \mathrm{~cm}$ of the logged section, hereafter referred as the active layer, are discordant on the underlying series and mainly composed of poorly consolidated fine-grained sand with 3D megaripples corresponding to dune deposits. The second unit, from 30 to $165 \mathrm{~cm}$ depth, is made of coarse-grained sandstones including centimeter-thick lenses of rounded pebbles, alternating with decimeter-thick carbonate-cemented gravel beds, including some loose pebbles and showing erosive bases. The unit is markedly impregnated by a carbonate cement with lenses of strongly cemented sand. 3D mega-ripples and horizontal laminations are observed. This unit is interpreted as fluvial deposits belonging to the Upper Cretaceous Bayanshire Formation.

The high sub-surface (profile P2) is more dissected, affected by several shallow fluvial incisions. It is paved by centimeter to decimeter-size pebbles and blocks of quatz and metamorphic rocks. The logged section is composed of 2 units. The first $25 \mathrm{~cm}$ of the $1 \mathrm{pp}^{r}$ unit 1 is composed of poorly

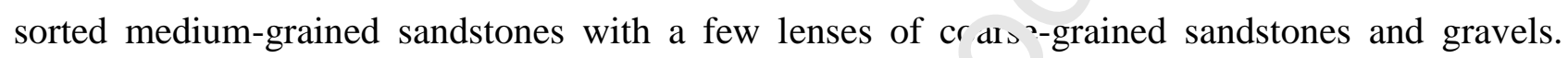
Faint 3D mega-ripples are visible. The next $30 \mathrm{~cm}$ beneat are massive coarse-grained sandstones with few gravelly layers and loose pebbles, strongly cc"solı lated by a carbonate cement. The base

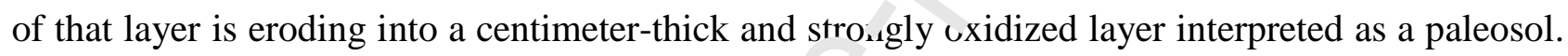
The bottom 15 centimeters of unit 1 is comper of horizontally laminated coarse-grained sandstones. Unit 1 is interpreted as low-en gy allu vial plain deposits. A second unit characterized by 10 to about $30 \mathrm{~cm}$-thick layers of gravels a.t coarse-grained sandstones with loose pebbles and cobbles extends from 70 to $190 \mathrm{~cm}$. The 'ase of each layer displays a sharp contact with the underlying deposits indicating syn-serin ar tary erosion. The unit is interpreted as channel deposits in an alluvial plain, again belongir g th the Upper Cretaceous Bayanshire Formation.

Profile P3 (samples MN17-61 to $\Lambda$ iN17-71) was sampled on the edge of the large ephemeral lake system forming the main $d \epsilon$ bres ion of the Zuunbayan sub-basin (Figure 11). The aim was to obtain erosion rates and/or surface ، ges in the lowest part of the basin. The surface in which profile P3 was excavated is characterized by meters-high aeolian dunes alternating with sand-free patches of red siltstone. The latter are covered by a near continuous one-grain thick layer of highly rounded gravels, 3 to 5 millimeters in diameter. The first $50 \mathrm{~cm}$ of the logged section are composed of massive red clay-rich siltstone including thin layers of coarse-grained sandstones. Mud cracks indicate drying periods between flooding events and these sedimentary facies are characteristic of the ephemeral lake. Below that first unit, the strata are composed of massive fine-grained sandstones showing fluvial 3D trough cross-bedding (Williams, 1968). Carbonate nodules are present within the uppermost $5 \mathrm{~cm}$ of that second unit. One to $5 \mathrm{~cm}$-thick layers of coarse-grained sandstones and gravels, some showing erosive bases, are regularly intercalated. This unit is 
interpreted as an arid alluvial plain deposit associating water-reworked sand dunes and small channels. The connection of the lower part of the profile to the Cretaceous series is more difficult to assess.

Profile 1 concentrations (Supplementary Table 1) are significantly higher at a given depth than those measured along Profiles 2 and 3 which both exhibit roughly similar cosmogenic nuclides concentrations. As shown in Figure 12, the evolution as a function of depth of the ${ }^{10} \mathrm{Be}$ and ${ }^{26} \mathrm{Al}$ concentrations of all the samples, except for the lower concentrations of the second sample of each profile (MN17-11 and MN17-37 at $5 \mathrm{~cm}$ ) as well as of sample MN17-62 at $20 \mathrm{~cm}$ in the Profile P3, exhibits the same pattern which corresponds to the expected exponential decrease. Highlighted for both ${ }^{10} \mathrm{Be}$ and ${ }^{26} \mathrm{Al}$ and for the three depth profiles, these lower cor entrations cannot be considered as outliers but most likely have a geomorphic explanation.

The sedimentary sections corresponding to each profile (Fig re :1d) display a surficial centimeterthick layer of small gravels to pebbles. This layer covers a 10 to $30 \mathrm{~cm}$ sandy layer that itself overlays the highly lithified Cretaceous strata in profi:'s 1 and 2. It seems that the sandy layers (active layer) in which MN17-11 (Profile 1), MN17 31 (Profile 2) and MN17-62 (Profile 3) have been sampled are affected by higher erosiot $1 . t ;$ that decrease the cosmogenic nuclides concentrations. Surprisingly, although $r$ slorging to the active layer, the surface sample concentrations are part of the expected exponenial decrease, implying that the top pebble layers can be modeled with the same parameters ( -95 son, exposure time) than the samples originating from the indurated sediment unit. To $b_{\text {an }}$. presented hereafter in Equation 2:

$$
\begin{array}{r}
\left.N(x, \varepsilon, t)=\frac{P_{\text {neut. }} \mathrm{e}^{\left(-x \rho / \Lambda_{\text {neut }} .\right.}}{\frac{\varepsilon \rho}{\Lambda_{\text {neut. }}}+\lambda} L^{1}-\mathrm{e}^{-t\left(\varepsilon \rho / \Lambda_{\text {neut. }}+\lambda\right)}\right]+\frac{P_{\text {stop. }} \mathrm{e}^{\left(-x \rho / \Lambda_{\text {stop. }} .\right)}}{\frac{\varepsilon \rho}{\Lambda_{\text {stop. }}}+\lambda}\left[1-\mathrm{e}^{-t\left(\varepsilon \rho / \Lambda_{\text {stop }}+\lambda\right)}\right] \\
+\frac{P_{\text {fast }} \mathrm{e}^{\left(-x \rho / \Lambda_{\text {fast }}\right)}}{\frac{\varepsilon \rho}{\Lambda_{\text {fast }}}+\lambda}\left[1-\mathrm{e}^{-t\left(\varepsilon \rho / \Lambda_{\text {fast }}+\lambda\right)}\right] \\
+\mathrm{N}(\mathrm{x}, \text { paleo }, \infty) \cdot \mathrm{e}^{(-\lambda \cdot \mathrm{t})} \quad \text { (Equation 2) }
\end{array}
$$

where the term $\mathrm{N}(0$, paleo $\varepsilon, \infty)$ of Equation 1 has been replaced by $\mathrm{N}(\mathrm{x}$, paleoc,,$)$, $\mathrm{x}$ being the sample depth. 
This is justified because these deposits are Cretaceous and therefore the ${ }^{10} \mathrm{Be}$ and ${ }^{26} \mathrm{Al}$ concentrations accumulated in the samples before their deposition in the studied profile (first inheritance) have decayed radioactively. Thus, the paleo-erosion rates determined in that case are not those prevailing before deposition but those prevailing after the deposition event, leading to exhumation of those Mesozoic series. Changing Equation 1 to Equation 2 only affects the paleoerosion rates and not the exposure ages and erosion rates. The best-fit solutions are presented in Supplementary Table 3 and in Figure 13. Uncertainties on paleo-erosion rates range from 0.5 to 1 $\mathrm{m} / \mathrm{Ma}$. Including or excluding the top surface sample from the calculation has an impact on the model outputs, especially regarding Profile 1. Therefore two groups of solution are proposed, with or without the top sample (Supplementary Table 3).

When considering the top samples into the calculation, the best its ior the three depth profiles lead to the similar exposure ages within uncertainties, the age df duc d from Profile 3 , nevertheless, is seemingly younger. However, major discrepancies are higı' 'ighted while analyzing the erosion and paleo-erosion rates. Regarding Profile 1 , the erosion $r_{c}$ e is $18.1 \pm 1.2 \mathrm{~m} / \mathrm{Ma}$ and the paleo-erosion rates range from 1.2 to $6 \mathrm{~m} / \mathrm{Ma}$ for the indurated $\Gamma_{-a}$ taceous unit and top samples with a median value of $3.3 \mathrm{~m} / \mathrm{Ma}$. The paleo-erosion and erosic $\mathrm{a}$ similar $(\sim 25 \mathrm{~m} / \mathrm{Ma})$. Profiles 2 and 3 ext bit similar erosion rates $(\sim 10 \mathrm{~m} / \mathrm{Ma})$ but significantly different paleo-erosion rates. Erosion rates fron Profile 2 range from 14.5 to $39.8 \mathrm{~m} / \mathrm{Ma}$ with a median value of $22.8 \mathrm{~m} / \mathrm{Ma}$, whereas in se from Profile 3 range from 1.1 to $51.1 \mathrm{~m} / \mathrm{Ma}$ with a median value of $3.7 \mathrm{~m} / \mathrm{Ma}$. Regardirso $\mathrm{P}_{1}$ iile 3, the top sample and the sample in the active layer has no evidence for inheritance. $\mathrm{R}$ əga ting Profiles 2 and 3, the active layer samples reveal erosion rates of 102.2 and $18.0 \mathrm{~m} / \mathrm{Ma}$, re nectively, higher than the erosion rate derived from the deeper samples.

Alternatively, considering $\therefore$ e top samples as outliers and excluding them from the calculation, has no effect on Profile 2, a limited effect on Profile 3, but has a considerable effect on Profile 1 for which the erosion rate decreases to $5.6 \pm 0.2 \mathrm{~m} / \mathrm{Ma}$ and the exposure age markedly increases to $1.64 \pm 0.45 \mathrm{Ma}$.

\section{Discussion}

\subsection{Fluvial and aeolian interactions in geologically complex depressions: a conceptual model}


The erosion pattern in a natural depression developing upon a substratum with contrasted erodibility implies strong interactions between fluvial mobilization and transport of detrital material and aeolian deflation and transport of the finer particles. Unlike in large pans such as the Etosha pan in Namibia (Hipodonka, 2005; Miller et al., 2010) or in wide sedimentary basins such as the Qaidam Basin in Tibet and China or the Lut Basin in Iran (Ehsani and Quiel, 2008; Heermance et al., 2013; Rohrmann et al., 2013), the occurrence of lithological contrasts generates erosion-resistant relief that form wind obstacles (Ruszkiczay-Rüdiger et al., 2011, Sebe et al., 2011).

The kinematics of airflow around topographic obstacles has been largely studied both theoretically and experimentally (Castro and Robins, 1977; Hunt et al., 1978; Smyth, 2016; Liu et al., 2019). The Tavan Har basement high, excluding the conical structure on its northern face is a flat-topped elongated structure with high aspect ratios of 2.75 and 80 for lengths v rsus width and height versus width respectively. The models addressing the surface flow struc $\cdots r_{\downarrow}$ over oblong artificial piles of granular material and natural ridges (Badr and Harion, 20r5, 907 ; Furieri et al., 2012; Liu et al., 2019) or transverse dunes (Jackson et al., 2013; Courrf in tu Pont et al., 2014; Smyth, 2016) are

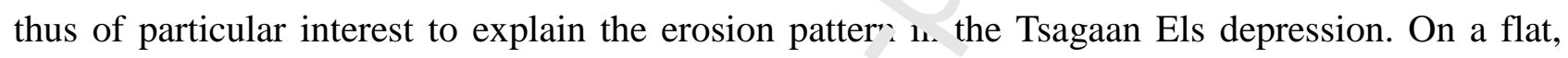
smooth terrain, the wind flow interacting with a lit te a ly limited oblong obstacle perpendicular to flow direction displays some characteristic f s $t u_{1}{ }^{\circ}$ (Badr and Harion, 2005, 2007; Furieri et al., 2012):

1- As for all obstacles, the increas in pressure on approaching the obstacle induces a deceleration of the flow. Since the wind transport capacity of sand particles is related to the wind speed (Bagnold, 1941), such decel srai ion should lead to deposition. When the change in slope at the toe of the obstacle is sharp, th:s phenomenon is partially compensated by the formation of turbulence that can produce _II 'lyn shear stress to allow some transport (Hunt et al., 1978; Wiggs et al., 1996). The wind flow then accelerates upslope as pressure drops, inducing a maximum shear stress along the windward $u$ est of the obstacle (Badr and Harion, 2005) thus increasing the erosion potential.

2- On the lee side of the obstacle, two counter-rotative and symmetrical vortices develop, leading to the formation of a low-shear stress region. Vortices form when the flow accelerated upslope of the upwind side of the obstacle detaches from the surface and interact with the slowmotion wind behind the obstacle. The strength of the vortices depends upon the difference in velocity and pressure between the two fluids (Hunt et al., 1978; Badr and Harion, 2005). The resulting triangular-like region of low shear stress is marked by deposition, a good example being the sand shadows and coppice dunes accumulated behind bushes (Figure 5C). 
3- The major perturbation in wind flow is a strong increase in shear stress on both ends of the obstacle, reaching a maximum value immediately downstream the extremities. In that region, the flow is accelerated on the upwind region and this acceleration adds to the downward motion of the flow in the vortices that form behind the obstacle (Badr and Harion, 2007; Furieri et al., 2012). Those regions, immediately behind each side of the obstacle are thus the locus of the maximum erosion. The shape and size of the acceleration zone is highly sensitive to the angle between the direction of the upcoming wind and the obstacle (Turpin and Harion, 2010; Furieri et al., 2012).

We suggest that these three main perturbations in the wind flow account for the morphology of the Tsagaan Els Basin (Figure 14). The conical structure configured within the Cretaceous strata on the northern side of the Tavan Har high is indeed covered by a thi- active layer of aeolian sand including small dunes - that disappears progressively upslope sxc $\cdot \mathrm{pt}$ in the extreme northeastern part of the massif where the sand sheet continues on the sumr II , lateau (Figure 2). Similarly, to the southwest, sand also reaches the summit of the massif how ver in a much smaller amount. Erosion rates calculated from the cosmogenic nuclide analysis $\cdot$ lso ncrease from the bottom to the top of the slope, reaching a regional maximum of 30 to $35 \mathrm{~m} / \mathrm{Ma}_{\mathrm{a}}$ on the crest (samples M-2 and M-8) (Figures 2 and 4). Sample M-7 was also collecte 1, tar the crest line of a small basement high that crops into the low part of the basin, probabl ex planing its relatively high erosion rate compared to samples M-5 and M-6 in the same position. Th 'e sand and erosion rate distribution patterns appear to match the theoretical model except that the location of the arcuate depression containing the ephemeral lakes at the toe of the conic 1 ,tructure north of the massif does not fit a decelerating flow. We suggest that the norther p.rt of the Unegt Basin is situated within the pressure shadow developing on the lee side of the Mandakh-Saykhandulaan ridge. The maximum wind velocity is thus reached in the central $\mathrm{\gamma} \mu \mathrm{n}$ ine basin where the small depressions filled with ephemeral lakes develop, away from the $1 .{ }^{\top} g_{c}$ shadow and before reaching the Tavan Har massif. Relative to the other erosion rates obtaine $\mathrm{i}$ n the basin, that area is marked by high erosion rates of 20 to $25 \mathrm{~m} / \mathrm{Ma}$ (Figure 4). Nonetheless, these rates remain low compared to values obtained in similar deflation studies such as $40-60 \mathrm{~m} / \mathrm{Ma}$ in the Pannonian Basin (Ruszkiczay-Rüdiger et al., 2011) or 120 $1100 \mathrm{~m} / \mathrm{Ma}$ in the Qaidam Basin (Kapp et al., 2011; Rohrmann et al., 2013). The ERA-Interim model (Figure 7) also suggests a maximum wind speed in the center of the Unegt Basin and a decrease on approaching the Tavan Har massif. Nonetheless, the model resolution does not allow imaging the upslope acceleration. Aeolian processes possibly initiated the formation of the depression in front of the Tavan Har massif, creating local base levels that triggered the formation of a new set of fluvial drainage systems eroding the southern slope of the Mandakh-Saykhandulaan 
ridge. Arid to semi-arid floodplains are major providers of fine-grained material to aeolian dune fields (Bullard and Livingstone, 2002; Bullard and McTainsh, 2003; Belnap et al., 2011). The ephemeral nature of all the rivers forming the drainage system in the Tsagaan Els depression leads to the deposition of thin planar sheets (flood sheets) or lobes of mud-supported sand, pebble and /or cobble conglomerates depending on the material available in the drainage system and on the water discharge (Dill et al., 2005). Due to the high rates of sediment supply during these discharges, and to their rapid flood recession characteristics, the surface of the deposits is poorly armored by the largest grains facilitating deflation of the silt and fine to medium sand fractions during dry intervals (Lisle and Hilton, 1992; Yao et al., 2007; Powell, 2009). Removing of the finest granulometric fraction through deflation typically produces the reg-type surfaces observed throughout the depression. The relatively fine-grained lithology of the Mesozoir se. as forming the substratum of the Tsagaan Els depression further enhances the production of ar.dy and silty material which is finally removed from the endoreic sub-systems by deflatios. Fin .lly, the ephemeral lakes that form the most distal part of the drainage sub-systems may al, $v_{\uparrow}$ lay a major role in facilitating material export through winnowing. Playas can be major dust ro 'iders for several reasons. For example, wet playas are generally characterized by a salt lay $r$ sn the surface, which, mixed with silt and clay represent material easily mobilizable by wir: lu. $n g$ dry periods (Reheis and Kihl, 1995; Reheis, 1997; Reynolds et al., 2007; Reheis and Urba . 2011). Fine grained material generally deposited in the playa is not only easily transported : $\mathrm{v}$ wind but is also easily mobilized by abrasion from saltating sand grains. This last phenom zr or may be increased by the occurrence of bushes creating wind disturbances that increase the ocaı shear stress (Pelletier, 2006). The present-day low annual precipitation favors deflation arant fluvial sedimentation preventing the local depressions from

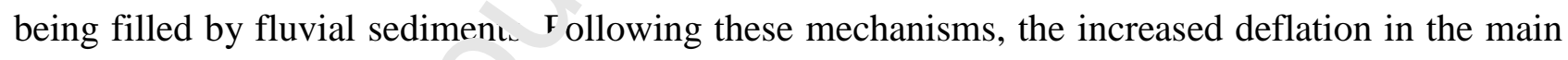
depression of the Zuunbu. ${ }^{\prime}$ a. su'sbasin may partly explain the occurrence of the large dune field that has developed immediatelv $\leqslant$ E of the major playa (Figures 1 and 4). Along the slope connecting the Mandakh-Saykhandulaan ridge with the central depression, sampling has been undertaken to avoid river channels so that the measured erosion rates reflect the surface erosion and not the activity of the intermittent channels. Nonetheless, some of the samples may still be affected by increased slope diffusion in the vicinity of large channels that was impossible to prevent during sampling. The heterogeneity observed in the erosion rates along that general slope reflects the strong increase of erosion capacity between the wind erosion characterized by low rates of 0 to $10 \mathrm{~m} / \mathrm{Ma}$ (dark and light blue points on Figure 4) and erosion rates up to $20 \mathrm{~m} / \mathrm{Ma}$ combining river-associated slopeerosion processes and wind deflation (light green points on Figure 4). 
The NE and SW depressions mapped immediately behind the Tavan Har massif correspond to the expected zone of combination between the flow acceleration around the extremities of the obstacle (Figure 2) and the down-flow region of the vortex that forms on the lee side. The mean wind direction in the Unegt Basin (blowing from $\mathrm{N} 315^{\circ}$ ) is slightly oblique through to perpendicular to the front of the Tavan Har massif $\left(\mathrm{N} 330^{\circ}\right)$, which, based on numerical models, should favor the northeastern high wind shear stress zone (Furieri et al., 2012). The direction of sand motion in the large sand sheet reaching the plateau to the NE clearly indicates a rotation in the wind direction from SE to E in accordance with the flow pattern observed on models (example.g., Furieri et al., 2012). To the NE, this region is also marked by highly variable sand-transport directions suggesting the formation of turbulence (Figure 8). The flow velocity and associated shear stress increasing from the axis of the massif towards the extremities, the deflation and abrasion capacities also increase ultimately carving the conical structure on the upwing ir 2 of the Tavan Har massif. A fluvial system developed on the conical structure (Figure ?), hri.lging loose material to the toe of the slope where wind shear stress and thus deflation is naximum. It should be noted that the increase in flow velocity associated to the extremities or the massif is not defined on the ERAInterim model (Figure 7) and the vortices observe $d$ in the model are not superposed with the NE and SW secondary depressions. This discrer ${ }^{\prime} c^{c}$ is probably related to the low resolution of the model compared to the high frequency - lov amplitude roughness of the topography (canyons or local highs in the basement for example).

The two vortices as well as the lower flo v velocity on the lee side of the massif are well defined on the ERA-Interim model (Figure 7, A rril 2019 and October 2016 panels). No major sand deposits are exposed behind the central pirt of the Tavan Har massif where such a wake zone should be expected, although small du a and sand shadows are present and sand motion directions are clearly turning before coming Topographically, the axial ı gion of the lee side is slightly higher than the surrounding Zunnbayan Basin, corresponding to a drainage divide between rivers flowing towards the main depression to the NE and a low point to the SW. Along the southern limit of the crystalline basement, present-day rivers are also flowing $\mathrm{NE}$ and $\mathrm{SW}$ from the axial zone, transporting loose material to the secondary depressions on each end of the massif. This material is then deflated by wind, maintaining the depressions as low points.

Based on the results derived from in situ-produced cosmogenic nuclide concentrations in both surface and profile samples, we infer that the dynamics of the erosion system in the Tsagaan Els depression may be also linked to climate changes. The area may have experienced a marked change 
in erosion rate from a value probably lower than $5 \mathrm{~m} / \mathrm{Ma}$ (many surface samples erosion rates as well as paleo-erosion rates derived from Profile 1 and 2 favor this value) to a rate higher than 10 $\mathrm{m} / \mathrm{Ma}$.

The erosion mechanism described above in the Tsagaan Els depression should apply to other depressions developing under semi-arid to arid climates but could also be complemented by processes evidenced in those regions. As already mentioned above, many studies have addressed the dynamics of aeolian transport in the western United States (California, Colorado and Utha, especially focusing on the source of the material, the production of dust and the effects of climate or anthropogenic changes (Muhs et al., 1996, 2003; Reheis, 1997, 2006; Reynolds et al., 2007; Reheis and Urban, 2011). This region is topographically complex, inclu 'ing numerous basement massifs surrounded by valleys hosting large dune fields. Based on the re sut presented above and although

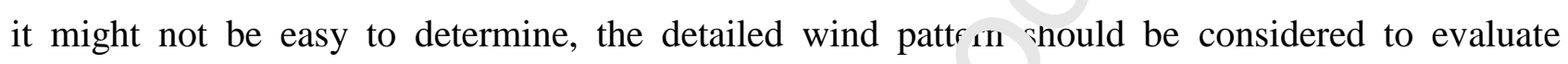
maximum deflation zones. In Africa, Wormald et al. (2002 established that the spatial distribution of pans in the Kalahari Desert of Botswana is correlat 1 to the occurrence of basement faults, the pans developing upon unconsolidated sands. Similarly, the still poorly understood Qattara depression in Egypt was developed within Cer $\jmath_{\mathbf{z}}$ is strata displaying lithological contrasts and tectonic fractures. To the north, upwind, tre o spression is limited by a cliff separating the basin from a plateau capped by carbonate rocks $\mathrm{WL}^{-1}{ }^{1} \mathrm{e}$ the strata exposed in the depression are mainly clastic (Albritton et al., 1990). Rivers ner ’ndicular and parallel to the cliff (Bassler, 1968) are mobilizing clastic material inside the (e. ression that feed dune fields to the south. Recently, McMillan and Schoenbohm (202C) 1 1 lated the formation of a large depression in the Puna Plateau (Argentina) to wind abrasion a.d deflation. However, they suggest that fluvial incision and transport played a minor re'c tue to the hyper-arid climate. Finally, Pullen et al. (2018) describe large-scale wind erosion (imuluding abrasion and deflation) in the Hami Basin (NW China) suggesting that the wind iıwnsity may be controlled by the low albedo of the dark-gravel armored basin floor. Although the Hami Basin is again a hyper-arid region, ephemeral drains remain active and could participate in the erosion by disturbing the gravel pavement.

\subsection{Climate change and the onset age of the present-day erosion mechanism in the Tsagaan Els depression}

Based on the results deduced from in situ-produced cosmogenic nuclide concentrations in both surface and profile samples, we infer that the kinematics of the erosion system in the Tsagaan Els 
depression is also linked to climate changes. Supplementary Table 2 shows that, for surface samples, when the measured age does not fit the modeled age $\left(\chi^{2}>0\right)$ considering option 1 , it does fit the modeled age using option 2 (or vice versa, except for a few samples). However, for option 2, the complex exposure approach is designed to determine burial ages (Granger and Muzikar, 2001; Granger 2006) and burial should not apply to those samples that clearly represent a newly formed active layer above the underlying substratum.

One possible explanation is a change in erosion rate. The landscape may have been first exposed for a long time at a certain erosion rate. Then, due to climatic or topographic disturbances, the longterm erosion rate may have changed towards a higher one. Theoretically, if the erosion rate decreases, the cosmogenic nuclide concentrations $\left({ }^{10} \mathrm{Be}\right.$ and ${ }^{26} \mathrm{~A}^{\prime \prime}$ should increase to reach new, higher equilibrium concentrations. The ${ }^{26} \mathrm{Al} /{ }^{10} \mathrm{Be}$ ratio would $\mathrm{nu}$. evolve along the steady state limit of the erosion island defined by Lal (1991, Figure 1$\lrcorner$ ). It the erosion rate increases, the cosmogenic nuclide concentrations $\left({ }^{10} \mathrm{Be}\right.$ and $\left.{ }^{26} \mathrm{Al}\right)$ accumu' ted during the previous step with lower denudation should decrease to reach new, lower equi' bril $\mathrm{n}$ concentrations. The ${ }^{26} \mathrm{Al} /{ }^{10} \mathrm{Be}$ ratio would then evolve in the burial area (below the steadv state erosion island defined by Lal, (1991)). This is illustrated in Figure 15 with an erosion $\mathrm{ra}$ ' nange from $3 \mathrm{~m} / \mathrm{Ma}$ (many surface sample erosion rates and Profile 1 and 2 paleo-erosi on $\mathrm{s}$ tes indicate values lower than $5 \mathrm{~m} / \mathrm{Ma}$ ) to $10 \mathrm{~m} / \mathrm{Ma}$ (the lower value observed in surface samples tr $\mathrm{n}$ the most actively eroding areas). This increase in erosion rate results in an apparent bur: $: 1$ a long as the new equilibrium concentrations are not reached. As this concentration decrea a i. volves radioactive decay, the time needed to "travel" from the starting point to the final one $\mathrm{c}$ in $i^{\text {a }}$ on the order of several million years (Figure 15). Following that model, the $1.64 \pm 0.45 \mathrm{Ma}$ exp sure age calculated on Profile 1 using the solution excluding the top sample (see section 3.5.2) can be explained as the time needed to decrease (mainly by radioactive decay) the inht. iteu component acquired in the Profile 1 samples before the erosion rate changes.

The actively eroding regions of the studied area thus probably experienced a change in erosion rate from an initial, regional low range of 1-8 m/Ma to a locally higher range of 18-22 m/Ma. This may explain the bimodal Kernel distribution of the erosion rates (Figure 9). Based on the exposure ages determined from the depth profiles, this shift in erosion rate may have occurred $0.7 \mathrm{Ma}$ ago, corresponding to the end of the middle Pleistocene transition (Clark et al., 2006; Sun et al., 2019). This age is also within the 0.4 to $1.1 \mathrm{Ma}$ range of exposure ages calculated following option 1 for the high erosion rates samples on the northern front of the Tavan Har massif (MN17-01 to MN1708, except MN17-05 for which the erosion rate is very low). This period corresponds to a major 
change in the frequency of glacial cycles during the Quaternary that resulted in an increase in Asian aridity and winter monsoonal intensity, enhancing soil degradation (less vegetation coverage (see for example Belnap et al., 2009 or Laity, 2013) and aeolian deflation (Clark et al., 2006; Han et al., 2012; Cai et al., 2014; Wang et al., 2020). Similar enhanced aeolian deflation has been reported from the Qaidam Basin (N Tibet, China) during glacial and stadial periods following the Middle Late Pliocene drying of the large lake system formerly filling the basin (Kapp et al., 2011). After 1.2 Ma, due to the generally drier climate and to tectonic activity, lakes in the Qaidam Basin were restricted to small fold-controlled depressions and frequently dried forming playas and locally increasing the deflation rates (Heermance et al., 2013).

\subsection{Possible effects on the aquifer pattern of semi-arid depres slo. 's}

The shallowest aquifers of the Tsagaan Els depression are ti shtl. controlled by the position of the topographic low points (Figures 1 and 2) (Grizard et al $\left.2{ }^{1} 19\right)$. The strong deflation in the main central depression of the Zuunbayan sub-basin thus c'ax-ly influences the flow pattern in the corresponding aquifers. In response, the position $r_{i}$ ie water table may also control the deflation rate in the playas: surface deflation is lower in dr: playas (water table at least $5 \mathrm{~m}$ below the surface) than in wet playas because the lack of in te action between the ground water and the surface prevents the formation of a surficial sait-rich easily erodible layer (Rosen, 1994; Reynolds et al., 2007). However, continuous deflation in :he secondary depression developing around the eastern corner of the Tavan Har basement $\mathrm{h}_{\mathrm{g}_{1}}$. may lead to the formation of a new evaporation-controlled discharge area, modifying the flo ' in the aquifers. The location of the preferential deflation zones probably changed through t:me, controlled by the modifications in the wind-flow pattern themselves linked to the ev lutı on of the general topography. In correlation, it can then be assumed that the location of the aqui 'r discharge zones have changed through time, modifying the shape of the underground flows. Furthermore, during wetter periods, the various depressions may be filled by lakes, again modifying the hydrological framework of the basin but also the erosion - deflation pattern. Indeed, the occurrence of lakes will suppress the role of the playas as dust sources and preferential deflation zones. This general increase in moisture and the probable stronger vegetation cover should favor fluvial processes and decrease aeolian deflation (Wolfe and Nickling, 1993; Bullard and Livingstone, 2002; Reynolds et al., 2007).

These processes require further exploration. Basins developed under semi-arid to arid climate regimes, and especially those evolving in an endoreic setting, are highly sensitive to climate changes and anthropogenic activities (Laity, 2003; Pelletier, 2006; Yapiyev et al., 2017; Wang et al., 
2018; Sankey et al., 2018b), one well-known example being the drying Aral sea in Central Asia. The data presented in this study suggest that not only the surficial water bodies but also the aquifers may be affected by changes in deflation patterns leading to complex issues in water management.

\section{Conclusions}

The erosion and sedimentation pattern in topographically and geologically complex arid to semiarid depressions is controlled by the close interplay between aeolian and fluvial processes. Unlike most large pans that develop upon a relatively homogeneous sedimentary substratum, the erosion pattern in such depressions is complex with preferential de ${ }^{7}$ tion zones controlled by the occurrence of erosion-resistant relief in mechanically less resis ${ }^{t} \mathrm{n}_{\iota}$ sedimentary series. The use of ERA-Interim reanalysis wind model complemented by fiel $\_$sapping of the sand displacement vectors around the Tavan Har basement high allows for a 'irect analogy between the wind pattern around that natural, large scale obstacle and the wind ${ }_{n}^{n}$ atter 1 predicted by theoretical analysis and numerical or analog modeling around a laterally limited obıung obstacle perpendicular to the wind flow. The acceleration of the wind flow around $t^{\prime} t \in+x^{+} i$ emities of the obstacles increases the shear stress allowing enhanced deflation and wir $\mathfrak{d}$ e osiun. This mechanism is further enhanced by the downflow of the two vortices developing on the lee side of the obstacle and account for the preferential deflation zones observed in the : Inegt and Zuunbayan sub-basins. These high deflation and wind erosion zones form base l'v ls for local drainage systems. The constant fluvial mobilization and transport of clas ic material towards these high deflation zones locally increases the erosion rates. Cosmogenic nu ${ }^{1}$ ide derived surface exposure ages of rapidly eroding zones in the basin suggest that this ero iv pattern was probably initiated as a consequence of the Middle Pleistocene regional incre $\mathbf{a}^{\mathrm{e}}$, $\mathrm{m}$ aridity. This conceptual model of constant interplay between fluvial mobilization of clastic mauılal and its removal from the sink area by deflation should be considered when evaluating erosion patterns in desert areas or assessing sediment production rates at the source of large dune fields. The modifications of the wind flow pattern through time, due to erosionrelated topographic changes inside the basin can also induce changes in the groundwater flows that should be taken into consideration in water management policies or when studying the various mineral deposits occurring in this type of complex basins.

\section{Acknowledgements}


This work has been financed by Orano. Field work was supported by Cogegobi who provided valuable administrative support and access to its logistics. All data relative to this work are included in the tables. We thank D. Virlogeux for field support and discussions on the regional geology. Two anonymous reviewers, A. East, P. Kapp, N.P. Mountney, Th. Pähtz, Z. Ruszkiczay-Rüdiger, Xiaoping Yang and Geomorphology Editor M. Stokes provided valuable comments to improve the initial manuscript. The ASTER AMS national facility (CEREGE, Aix-en-Provence) is supported by the INSU/CNRS, the ANR through the "Projets thématiques d'excellence" program for the "Equipements d'excellence" ASTER-CEREGE action and IRD. RB thanks G. Leduc for fruitful discussions. We declare no competing financial interest. The data used are listed in the Supplementary Tables. We would like to dedicate this manuscrip to our friend and member of the ASTER Team Didier Bourlés (04/1955 - 03/2021).

\section{References}

Albritton C.C., Brooks J.E., Issawi B., Swedan A., 1990. Origin of the Qattara Depression, Egypt. Geological Society of America Bulletin, 102, 952-960.

Al-Masrahy M.A., Mountney N.P., 2015. A classification scheme for fluvial-aeolian system interaction in desert-margin settings. Aeolian Research, 17, 67-88. 
Aref M.A.M., El-Khoriby E., Hamdan M.A., 2002. The role of salt weathering in the origin of the Qattara Depression, Western Desert, Egypt. Geomorphology, 45, 181-195.

Bagnold R.A., 1941. The Physics of Blown Sand and Desert Dunes. Mathuen, London.

Barchyn T.E., Hugenholtz C.H., 2013. Reactivation of supply-limited dune fields from blowouts : A conceptuel framework for state characterization. Geomorphology, 201, 172-182.

Badr T., Harion J.L., 2005. Numerical modeling of flow over stockpiles: Implications on dust emissions. Atmospheric Environment, 39, 5576-5584.

Badr T., Harion J.L., 2007. Effect of aggregate storage piles configuration on dust emissions. Atmospheric Environment, 41, 360-368.

Bassler F., 1968. Scheme for the Qattara Depression. Water Pow r, D zcember 1968, 494-498.

Belnap J., Lange O.L., 2001. Central Asia Takyr. In Biologi $a_{i}$ S $r$ l Crusts: Structure, Function, and Management, Springer, 2001, ISBN 3-540-4375 $1-\iota^{-}$

Belnap J., Reynolds R.L., Reheis M.C., Phillips S.L. U.ban ז.E., Goldstein H.L., 2009. Sediment losses and gains across a gradient of live tt $\cdot k$ grazing and plant invasion in a cool, semiarid grassland, Colorado Plateau, UjA Aeclian Research, 1, 27-43.

Belnap J., Munson S.M., Field J.P., 2011. Aeolın ? and fluvial processes in dryland regions : the need for integrated studies. Ecch va $\mathbf{a}_{\mathbf{1}} \log \mathrm{y}, 4,615-622$.

Blackwelder E., 1934. Yardangs. Gerng ^.. Society of America Bulletin, 45, 159-166.

Borchers B. Marrero S., Balco C Caifee M., Goehring B., Lifton N., Nishiizumi K., Phillips F., Schaefer J., Stone : 2,16. Geological Calibration of Spallation Production Rates. Quaternary Genchı ono jgy, 31, 188-198.

Braucher R., Merchel S Borgomano J., Bourlès D.L., 2011. Production of cosmogenic radionuclides at great depth : A multi element approach. Earth and Planetary Science Letters, 309, 1-9.

Bullard J.E. and Livingstone I., 2002. Interactions between aeolian and fluvial systems in dryland environment. Area, 34.1, 8-16.

Bullard J.E. and McTainsh G.H., 2003. Aeolian-fluvial interactions in dryland environments : examples, concepts and Australia case study. Progress in Physical Geography, 27.4, 471501. 
Cai Maotang, Wei Mingjian, Yang Yibo, Wang Junping, Xu Dainan, 2014. Long-term cooling/drying record of North China since the middle Pleistocene from geochemical evidence of a $150 \mathrm{~m}$ deep drill core, Beijing plain, China. Quaternary International, 349, 419-427.

Castro I.P., Robins A.G., 1977. The flow around a surface-mounted cube in uniform and turbulent streams. Journal Fluid Mechanics, 79, 307-335.

Caves J.K., Sjostrom D.J., Mix H.T., Winnick M.J., Chamberlain C.P., 2014. Aridification of Central Asia and uplift of the Altai and Hangay Mountains, Mongolia: Stable isotope evidence. American Journal of Science, 314, 1171-1201.

Clark, P.U., Archer D., Pollard D., Blum J.D., Rial J.A., Brovkin V Nix A.C., Pisias N.G., Roy M., 2006. The middle Pleistocene transition: characteristics ne hanisms, and implications for long-term changes in atmospheric pCO2. Quaterna y Sci _nce Reviews, 25, 3150-3184.

Courrech du Pont, S., Narteau C., Gao Xin, 2014. Two · odı s for dune orientation. Geology, 42.9, 743-746.

Crosby B.T., and Whipple K.X., 2006. Knickpoir inıuation and distribution within fluvial networks: 236 waterfalls in the Waipaoa Rivc - N' orth Island, New Zealand. Geomorphology, 82, 1638.

Currie, P.J., and Eberth, D.A., 1993. Pa.a o ıology, sedimentology and palaeoecology of the Iren Dabasu Formation (Upper 'retaceous), Inner Mongolia, People’s Republic of China. Cretaceous Research, 11 1.?7-144.

Daoudene Y., Gapais D., Cc sı' J-r., Ruffet G., 2017. Late Jurassic - Early Cretaceous continental extension in nortı 'ası Asia - Relationships to plate kinematics. Bulletin de la Société Géologique de France, 188, 10.

Dee, D., et al. (2011), The ERA-Interim reanalysis: Configuration and performance of the data assimilation system, Quaterly Journal of the Royal Meteorological Society, 137 (656), $553-597$.

Dill H.G., Khishigsuren S., Majigsuren Yo., Myagmarsuren S., Bulgamaa J., 2006. Geomorphological studies along a transect from the taiga to the desert in Central Mongolia - Evolution of landforms in the mid-latitude continental interior as a function of climate and vegetation. Journal of Asian Earth Sciences, 27, 241-264. 
Draut A.E., 2012. Effects of river regulation on aeolian landscapes, Colorado River, southwestern USA. Journal of Geophysical Research, 117, F02022, doi:10.1029/2011JF002329.

Ehsani A.H., and Quiel F., 2008. Application of Self Organizing Map and SRTM data to characterize yardangs in the Lut desert, Iran. Remote Sensing of Environment, 112, 32843294.

Furieri B., Russeil S., Harion J.L., Turpin C., Santos J.M., 2012. Experimental surface flow visualization and numerical investigation of flow structure around an oblong stockpile. Environmental Fluid Mechanics, 12, 533-553.

Gao Xin, Narteau C., Rozier O., 2015, Development and steady states of transverse dunes : A numerical analysis of dune pattern coarsening and giant dh.. as. Journal of Geophysical Research : Earth Surface, 120, 2200-2219.

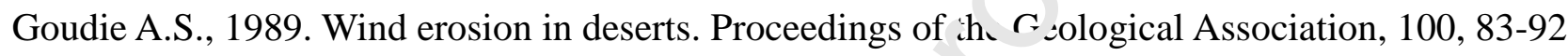

Goudie A.S., 1991. Pans. Progress in Physical Geograph y, 1: .3, 221-237.

Goudie A.S. and Wells G.L., 1995. The nature, distriv tion and formation of pans in arid zones. Earth-Science Reviews, 38, 1-69

Graham, S.A., Hendrix, M S., Johnson, C.L., `adamgarav, D., Badarch, G., Amory, J., Porter, M., Barsbold, R., Webb, L.E., Hackeı, B.R., 2001. Sedimentary record and tectonic implications of late Mesozoic if ir y, southeast Mongolia. Geological Society of America Bulletin, 113, 1560-1579.

Granger D. E., and Muzikar P. F., 20u1. Dating sediment burial with in situ-produced cosmogenic nuclides: theory, te $\mathbf{m i n}$ : ques, and limitations. Earth and Planetary Science Letters, 188, 269-281.

Granger D.E., 2006. A reviuw of burial dating methods using 26Al and 10Be. In In situ-produced cosmogenic nuclides and quantification of geological processes (Eds. Siame, L., Bourlès, D.L., and Brown, E.T.). Geological Society of America Special Paper, 415, 1-16.

Grizard P., 2017. Fonctionnement hydrogéologique et hydrochimique du bassin crétacé de Tsagaan Els (Dornogobi, Mongolie). PhD, Paris Science and Lettres Research University, 350 p.

Grizard P., Schmitt J-M., Goblet P., 2019. Hydrogeology of an arid endorheic basin (Tsagaan Els, Dornogobi, Mongolia) : field data and conceptualization, three-dimensional groundwater modeling, and water budget. Hydrogeology Journal, doi.org/10.1007/s 10040-018-1868-1 
Han Wenxia, Fang Xiaomin, Berger A., 2012. Tibet forcing of mid-Pleistocene synchronous enhancement of East Asian winter and summer monsoons revealed by Chinese loess record. Quaternary Research, 78, 174-184.

Heermance R. V., Pullen A., Kapp P., Garzione C. N., Bogue S., Ding L., Song P., 2013. Climatic and tectonic controls on sedimentation and erosion during the Pliocene-Quaternary in the Qaidam Basin (China). Geological Society of America Bulletin, 125, 833-856.

Hesp P., 2002. Foredunes and blowouts : initiation, geomorphology and dynamics. Geomorphology, $48,245-268$

Hipondaka M.H.T., 2005. The development and Evolution of Etos' 1 a Pan, Namibia. PhD thesis, University Würzburg, 152 p.

Hunt J.C.R., Abell C.J., Peterka J.A., Woo H., 1978. Kinemat eai studies of the flows around free or surface-mounted obstacles ; applying topology to \& ow visualization. Journal of Fluid Mechanisc, 86.1, 179-200.

Iversen J.D., Wang Wen-Ping, Rasmussen K.R., Mi'sk Isen H.E., Hasiuk J.F., Leach R.N., 1990. The effect of a roughness element on los 1 saıtation transport. Journal of Wind Engineering and Industrial Aerodynamics, 36, ¿ 15- 354.

Jackson D.W.T., Beyers M., Delgado-Fern ndez I., Baas A.C.W., Cooper A.J., Lynch K., 2013. Airflow reversal and alternatir.g co kscrew vortices in foredune wake zones during perpendicular and oblique : ffshure winds. Geomorphology, 187, 86-93.

Johnson C.L., 2004. Polyphase ev'lution of the East Gobi basin : sedimentary and structural records of Mesozo _-_enozoic intraplate deformation in Mongolia. Basin Research, 16, 79-99.

Johnson, C.L.,Webb, L.E., Graham, S.A., Hendrix, M.A. \& Badarch, G., 2001. Sedimentary and structural records of late Mesozoic high-strain extension and strain partitioning, East Gobi basin, southern Mongolia. Geological Society of America Bulletin, 194, 413-434.

Jolivet M., Ritz J-F., Vassallo R.,Larroque C., Braucher R., Todbileg M., Chauvet A., Sue C., Arnaud N., De Vicente R., Arzhanikova A., Arzhanikov S., 2007. The Mongolian summits: An uplifted, flat, old but still preserved erosion surface. Geology, 35.10, 871-874. 
Kapp P., Pelletier J.D., Rohrmann A., Heermance R., Russel J., Ding L., 2011. Wind erosion in the Qaidam basin, central Asia : Implications for tectonics, paleoclimate, and the source of the Loess Plateau. GSA Today, 21.4/5, https://doi.org/10.1130/GSATG99A.1

Kapp P., Pullen A., Pelletier J.D., Russell J., Goodman P., Cai F., 2015. From dust to dust : Quaternary wind erosion of the Mu Us Desert and Loess Plateau, China. Geology, 43, 835838, doi:10.1130/G36724.1

Krapf C.B.E., Stollhofen H., Stanistreet I.G., 2003. Contrasting styles of ephemeral river systems and their interaction with dunes of the Skeleton Coast erg (Namibia). Quaternary International, 104, 41-52.

Laity J.E., 1987. Topographic effects on ventifact development, $M_{1}$ `ave Desert, California. Physical Geography, 8, 113-132.

Laity J., 2003. Aeolian destabilization along the Mojave Rive', rv' jave Desert, California :

Linkages among fluvial, groundwater, and aeolian vstems. Physical Geography, 24.3, 196221, https://doi.org/10.2747/0272-3646.24.3.10 $;$

Laity J.E., 2011. Wind erosion in drylands. In Thomas L.S.G. (Ed), Arid Zone Geomorphology. Process, Form and Change in Drylands. $\mathrm{W}$ “er \& Sons, UK.

Lamb, M.A., Hanson, A.D., Graham, S.A., ' 'ad Arch, G., Webb, L.E., 1999. Left- lateral sense offset of upper Proterozoic to Paleozc - features across the Gobi Onon, Tost, and Zuunbayan faults in southern Mongolia ar 11 . nnications for other Central Asian faults. Earth and Planetary Science Letters, 1/0, 103-194.

Lisle T.E. and Hilton S., 1992. The vlume of fine sediment in pools: An index of sediment supply in gravel-bed streams. $V^{\top}{ }^{\top}$ er Resources Bulletin, 28, 371-383.

Liu Baoli and Coulthard '1.' , _U15. Mapping the interactions between rivers and sand dunes: Implications for fıuvial and aeolian geomorphology. Geomorphology, 231, 246-257.

Liu Baoli and Coulthard T.J., 2017. Modelling the interaction of aeolian and fluvial processes with a combined cellular model of sand dunes and river systems. Computers \& Geosciences, 106, $1-9$.

Liu Zhenqing, Diao Zheng, Ishihara T., 2019. Study of the flow fields over simplified topographies with different roughness conditions using large eddy simulations. Renewable Energy, 136, 968-992. 
Maroulis J.C., Nanson G.C., Price D.M., Pietsch T., 2007. Aeolian-fluvial interaction and climate change: source-bordering dune development over the past $~ 100 \mathrm{ka}$ on Cooper Creek, central Australia. Quaternary Science Reviews, 26, 386-404.

McMillan M. and Schoenbohm L.M., 2020. Large-scale Cenozoic wind erosion in the Puna Plateau : The Salina del Fraile Depression. Journal of Geophysical Research - Earth Surface, 125, e2020JF005682, https://doi.org/10.1029/2020JF005682.

Middleton N.J., 1991. Dust storms in the Mongolian People's Republic. Journal of Arid Environments, 20, 287-297.

Miller R.McG., Pickford M., Senut B., 2010. The geology, palaeontology and evolution of the Etosha Pan, Namibia : Implications for terminal Kalahari u nosition. South African Journal of Geology, 113.3, 307-344.

Mountney N.P., 2006. Eolian facies models. In Posamentier F. $I^{\prime}{ }^{a}$ d Walker R.G. (Eds), Facies models revisited, SEPM special publication, Tuls ‘, '́l'lahoma, USA, 84, 19-83.

Mountney N.P., Russell A.J., 2009. Aeolian dune-field de velop.nent in a water table-controlled system: Skeiđarársandur, Southern Iceland. Sedim zn. v1r gy, 56, 2107-2131.

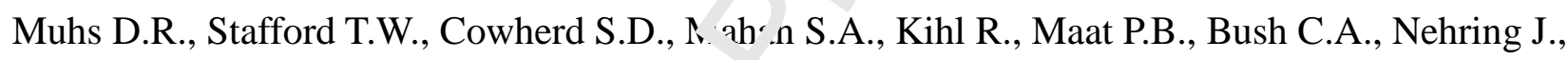
1996. Origin of the late Quaterı `ry dune firlds of northeastern Colorado. Geomorphology, $17,129-149$.

Muhs D.R., Reynolds R.L., Been J., s $\mathrm{K}_{\mathrm{L}} \cap \mathbf{\mathrm { N }}$., 2003. Eolian sand transport pathways in the southwestern United Stat : inıportance of the Colorado River and local sources. Quaternary International, 104, 3-19

Natsagdorj L., Jugder D. Cl ung Y.S., 2003. Analysis of dust storms observed in Mongolia during 1937 - 1999. Atmos, heric Environment, 37, 1401-1411.

Naugolnykh S.V., 2016. Upper Cretaceous Paleosols of the Bain-Dzak Section, Southern Mongolia. Paleontological Journal, 50.12, 1451-1469.

Pelletier J.D., 2006. Sensitivity of playa windblown-dust emission to climatic and anthropogenic change. Journal of Arid Environments, 66, 62-75.

Powell D.M., 2009. Dryland Rivers : Processes and Forms. In Parsons A.J. and Abrahams A.D. (Eds), Geomorphology of the Desert Environments. Second Edition, Spinger Science+Business Media. 
Pullen A., Kapp P., Chen N., 2018. Development of stratigraphically controlled, eolian-modified unconsolidated gravel surfaces and yardang fields in the wind-eroded Hami Basin, northwestern China. Geological Society of America Bulletin, 130.3/4, 630-648, https://doi.org/10.1130/B31734.1

Reheis M .C., 1997. Dust deposition downwind of Owens (dry) Lake, 1991-1994 : Preliminary findings. Journal of Geophysical Research, 102.D22, 25999-26008.

Reheis M.C., 2006. A 16-year record of aeolian dust in Southern Nevada and California, USA : Controls on dust generation and accumulation. Journbal of Arid Environments, 67, 487520.

Reheis M.C. and Kihl R., 1995. Dust deposition in southern Nevada and California, 1984-1989 : Relations to climate, source area, and source lithology. Jnirna' of Geophysical Research, 100.D5, 8893-8918.

Reheis M.C. and Urban F.E., 2011. Regional and climatic cc a $1 \mathrm{~s}$ on seasonal dust deposition in the southwestern U.S. Aeolian Research, 3, 3-21.

Reynolds R.L., Yount J.C., Reheis M., Goldstein H., ChəVc.'(Jr.) P., Fulton R., Whitney J., Fuller C., Forester R., 2007. Dust emission from wet a'd dry playas in the Mojave Desert, USA. Earth Surface Processes and Landfo... s, ¿? , 1811-1827.

Rixhon G., Braucher R., Bourlès D., Siame L. Bovy B., Demoulin A. Quaternary river incision in NE Ardennes (Belgium) - Insights ‘rom 10Be/26Al dating of river terraces. Quaternary Geochronology 6 (2011) 273-2¿ 4

Rohrmann A., Heermance R., Kapr ?., Cai Fulong, 2013. Wind as the primary driver of erosion in the Qaidam Basin, Chir э. ₹arth and Planetary Science Letters, 374, 1-10.

Rosen M.R., 1994. The imp's nce of groundwater in playas : a review of playa classification and the sedimentolog, ?ाu hydrology of playas. In Paleoclimate and Basin Evolution of Playa Systems, Geologicu Society of America Special Paper 289, Rosen M.R. (ed.). Boulder, Colorado, USA, 1-18.

Ruszkiczay-Rüdiger Z., Fodor L.I., Horváth E., 2007. Neotectonics and Quaternary lansdcape evolution of the Gödöllö Hills, Central Pannonian Basin, Hungary. Global and Planetary Change, 58, 181-196.

Ruszkiczay-Rüdiger Z., Fodor L., Horváth E., Telbisz T., 2009. Discrimination of fluvial, aeolian and neotectonic features in a low hilly landscape: A DEM-based morphotectonic analysis in the Central Pannonian Basin, Hungary. Geomorphology, 104, 203-217. 
Ruszkiczay-Rüdiger Z., Braucher R., Csillag G., Fodor L.I., Dunai T.J., Bada G., Bourlès D., Müller P., 2011. Dating Pleistocene aeolian landforms in Hungary, Central Europe, using in situ produced cosmogenic ${ }^{10}$ Be. Quaternary Geochronology, 6, 515-529.

Sankey J.B., Kasprak A., Caster J., East A.E., Fairley H.C., 2018a. The response of sourcebordering aeolian dunefields to sediment-supply changes 1 : Effects of wind variability and river-valley morphodynamics. Aeolian Research, 32, 228-245.

Sankey J.B., Caster J., Kasprak A., East A.E., 2018b. The response of source-bordering aeolian dunefields to sediment-supply changes 2 : Controlled floods of the Colorado River in Grand Canyon, Arizona, USA. Aeolian Research, 32, 154-169.

Santos M.G.M., Hartley A.J., Mountney N.P., Peakall J., Owen A. Merino E.R., Assine M.L., 2019. Meandering rivers in modern desert basins: Implications for c hannel planform controls and prevegetation rivers. Sedimentary Geology, 385, 1-14

Sebe K., Csillag G., Ruszkiczay-Rüdiger Z., Fodor L., Thar `ó Rr Łsó E., Müller P., Braucher R., 2011. Wind erosion under cold climate: A Pleist « ne periglacial mega-yardang system in Central Europe (Western Pannonian Basin, Hur ga.:). Geomorphology, 134, 470-482.

Siame L., Bellier O., Braucher R., Sébrier M., Cusl ir g M., Bourlès D.L., Hamelin B, Baroux E.,

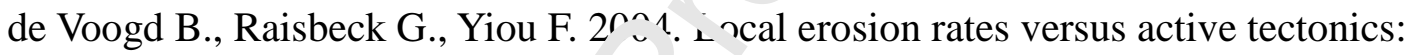
Cosmic ray exposure modelling in $\mathrm{t}$. vence (South-East France), Earth and Planetary Science Letters, 220, 345-364.

Simmons, A., Uppala S., Dee D., Kohaya stı S., 2007. ERA-interim: New ECMWF reanalysis products from 1989 onwa ds. ECMWF Newsletter, 110, 25-35.

Smith W.H.F., and Wessel P., 1990. Gridding with continuous curvature splines in tension. Geophysics, 55 2, 3-31 5.

Smyth T.A.G., 2016. A revie' $v$ of Computational Fluid Dynamics (CFD) airflow modelling over aeolian landforms. Aeolian Research, 22, 153-164.

Stone, J. O. , 2000. Air pressure and cosmogenic isotope production. Journal of Geophysical Research, 105 (B10), 23753-23759.

Sun, Y., Yin, Q., Crucifix, M, Clemens S. C., Araya-Melo P., Liu W., Qiang X., Liu Q., Zhao H., Liang L., Chen H., Li Y., Zhang L, Dong G., Li, . Zhou W., Berger A., An Z. 2019. Diverse manifestations of the mid-Pleistocene climate transition. Nature Communication, 10, 352. 
Tominaga Y., Okaze T., Mochida A., 2018. Wind tunnel experiment and CFD analysis of sand erosion/deposition due to wind around an obstacle. Journal of Wind Engineering \& Industrial Aerodynamics, 182, 262-271.

Turpin C., Harion J.L., 2010. Effects of the topography of an industrial site on dust emissions from open storage yards. Environmental Fluid Mechanics, 10, 677-690.

Vassallo R., M. Jolivet, J-F Ritz, R. Braucher, Ch. Larroque, C. Sue, M. Todbileg, D. Javkhlanbold, 2007. Uplift age and rates of the Gurvan Bogd system (Gobi-Altay) by apatite fission track analysis. Earth Planetary Sciences Letter, 259, 333-346.

Vermeesch, P. (2007), CosmoCalc: An Excel add- in for cosmogeric nuclide calculations,

Geochem. Geophys. Geosyst., 8, Q08003, doi:10.1029/20 nar Ic'001530.

Vermeesch, P., 2012. On the visualisation of detrital age distrikntlu. Chemical Geology, 312-313, 190-194, doi: 10.1016/j.chemgeo.2012.04.021 0

Wakes S.J., Maegli T., Dickinson K.J., Hilton M.J., 201? Nu nerical modelling of wind flow over a complex topography. Environmental Modeling \& Suftware, 25, 237-247.

Wang Jida, Song Chunqiao, Reager J.T., Yao Far ${ }_{i}$ fang, Famiglietti J.S., Sheng Yongwei, MacDonald G.M., Brun F., Müller _cr mied H., Marston R.A., Wada Y., 2018. Recent global decline in endorheic basi. water storage. Nature Geoscience, 11, 926-932.

Wang Wanfu, Dong Zhibao, Wang Tao, Z aang Guobin, 2006. The equilibrium gravel coverage of the deflated gobi above the Mogao Grottoes of Dunhuang, China. Environmental Geology, 50, 1077-1083.

Wang Xin, Dettman D.L., W dne Mi, Zhang Jinhui, Saito Y., Quade J., Feng Song, Liu Jianbao, Chen Fahu, 2020. Seasonal wet-dry variability of the Asian monsoon since the middle Pleistocene. Quateınary Science Reviews, 247, 106568.

Webb L.E., Johnson C.L., 2006. Tertiary strike-slip faulting in southeastern Mongolia and implications for Asian tectonics. Earth and Planetary Science Letters, 241, 323-335.

Wessel P., and Smith W.H.F., 1991. Free software helps map and display data. EOS Transactions American Geophysical Union, 72, 441, 445-446.

Wiggs G.F.S., Livingstone I., Warren A., 1996. The role of streamline curvature in sand dune dynamics: evidence from field and wind tunnel measurements. Geomorphology, 17, 2946. 
Williams G.E., 1968. Formation of large-scale trough cross-stratification in a fluvial environment. Journal of Sedimentary Petrology, 38(1), 136-140.

Williams M., 2015. Interactions between fluvial and aeolian geomorphic systems and processes: Examples from the Sahara and Australia. Catena, 134, 4-13.

Whipple K.X., and Tucker G.E., 1999. Dynamics of the stream-power river incision model: Implications for heigh limits of mountain ranges, landscape response timescales, and research needs. Journal of Geophysical Research, 104.B8, 17661-17674.

Wolfe S.A. and Nickling W.G., 1993. The protective rôle of sparse vegetation in wind erosion. Progress in Physical Geography, 17, 50-68.

Wolkowinsky A.J. and Granger D. E.,2004. Early Pleistocene incis:n vf the San Juan River, Utah, dated with $26 \mathrm{Al}$ and 10Be Geology, 32 (9), 749-752.

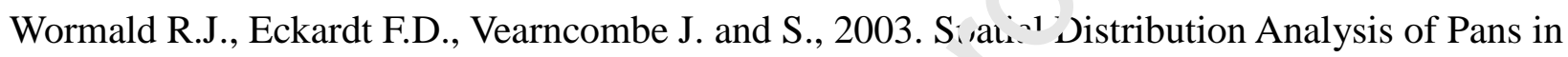
Botswana : The Importance of Structural Contrr 1. . Touth African Journal of Geology, 106, 287-290.

Yapiyev V., Sagintayev Zh., Inglezakis V.J., Samc iki. ar. .ov K., Verhoef A., 2017. Essentials of endorheic basins and lakes: A revie $N$ ir the context of current and future water ressource management and mitigation activities is. Central Asia. Water, 9, 798; doi:10.3390/w9100798.

Yao Z.Y., Wang T., Han Z.W., Zhans W. M., Zhao A.G., 2007. Migration of sand dunes on the northern Alxa Plateau, In. ar Miongolia, China. Journal of Arid Environments, 70, 80-93. 


\section{Figure captions}

Figure 1: A: Large scale satellite image (Google Earth ${ }^{\circledR}$, Landsat Images, Copernicus) showing the Tsagaan Els depression and surrounding basement ridges with indication of the major faults (Graham et al., 2001). The dotted lines represent the $750 \mathrm{~m}$ altitude contour line that highlights the lowest parts of the depression. B: 1 arc second resolution Shuttle Radar Topography Mission (SRTM1) Digital Elevation Model (DEM) documenting the topography of the Tsagaan Els depression. The red and blue lines correspond to the track of the topographic profiles shown at the bottom of the figure. The DEM and profiles were drawn using the GMT Software (Smith and Wessel, 1990). On profiles 1 and 2, the thick colored line represent the mean altitude of a staked series of individual profiles sampled every $\mathrm{km}$ over $5 \mathrm{~km}$ on each i les of the indicated profile track. The grey envelope indicates the altitude dispersal. Note that vert cat 'xaggeration is $\mathrm{x} 20$. Data were acquired every $20 \mathrm{~m}$ from the SRTM1 DEM.

Figure 2: Geological map of the Tavan Har structure and its surroundings (modified from Grizard, 2017). Piezometric lines represent the aquifer in the Las ${ }^{2}$,retaceous Upper Sainshand Formation (K2Ss2) and have been simplified from Grizard et ‘. (2019). BB: Baruun Bayan spring; DB: Dund Bayan spring. BP: Bayanshire Plateau (the lim: ${ }^{\prime}$ or the plateau are indicated by a dotted line). Arrows on faults indicate sense of moveme. ${ }^{+}$

Figure 3: Field photographs of the Tavar $\mathrm{H}$ ar structure (see Figure 2 for location): a) view from the NE of the Tavan Har basement hig, and the conical structure (labelled morphological cone) to the north. Note the flat summit of t'- $t_{\text {. }}$ sement high. The distance scale applies to the background. b) the Cretaceous series cropping c in the conical structure are tilted and clearly not parallel to the morphological surface. 're the de dashed lines indicate bedding. c) views of the southern edge of the basement high, showir? he morphological scarp corresponding to the differential erosion along the Cretaceous normal faults. Only the Lower Cretaceous series are exposed. d) view of the summit plateau on the basement high. The surface covered with sand (background) is separated from the sand-free foreground by a small canyon incised in the basement. e) aeolian deposits and thin gravel layer on the conical structure. These are the only sediments deposited on that surface and do not correspond to an alluvial fan. f) Colluvium on the metamorphic basement. These deposits are formed by largely in-situ produced unsorted and sharp-edged basement-rock fragments. The camera lens cover is $5 \mathrm{~cm}$ in diameter. 
Figure 4: Simplified geological and tectonic map of the Tsagaan Els depression. Only the largest dune fields and sand sheets are shown; the rest of the surface is largely free of sand and covered by desert pavements of gravel. Similar to Figure 1, the $750 \mathrm{~m}$ contour line highlights the lowest depressions in the basin. Erosion rates calculated from cosmogenic ${ }^{10} \mathrm{Be}$ and ${ }^{26} \mathrm{Al}$ concentrations measured in surface samples are indicated as color-coded rectangles. See Supplementary Tables 1 and 2 for details on results from cosmogenic nuclides analysis.

Figure 5: Satellite and field photographs of aeolian features in the Tsagaan Els depression. a) Satellite images (Google Earth ${ }^{\circledR}$ CNES/Airbus 2021 and Maxar Technologies 2021) of the large dune fields east of the Zuunbayan sub-basin (Figures 1 and 4) showing parabolic and transverse dunes. b) Satellite images (Google Earth $^{\circledR}$ Maxar Technologies 2021) and field photograph of longitudinal dunes developing immediately south of an epher tera' lake north of the Tavan Har conical structure. c) Field view of a reg-type landscape on r $\mathrm{ml}_{\mathrm{h}} \mathrm{h}$ only the vegetation allows sand accumulation. To the right, small-scale sand shadow behiı' ' a bush. Such accumulations can be up to several meters in length and about 1 meter in hei $\varepsilon_{\varepsilon}$ t ('oppice dunes). The dotted line white arrows indicate the sand motion direction for each image.

Figure 6: Meteorological data from the Sain rana (left) and Bayandobosuma (right) weather stations (Figure 1) as recorded in the Clima. $J$, ata Online catalog of the U.S. National Oceanic and Atmospheric Administration. The botton. right diagram shows the compilation of storm conditions (wind speed over $30 \mathrm{~m} . \mathrm{s}^{-1}$ ) for the $\mathrm{S}_{\mathrm{in}} \mathrm{i}$ and station. $\mathrm{N}$ represents the number of data for each diagram. The small "+" characters on ' he temperature diagrams and the starts on the precipitation diagrams indicate the outliers.

Figure 7: Examples of wi id $\mathrm{p}$ attern obtained using the ERA-Interim reanalysis data. The three models to the left correspon' to monthly averages. Note the formation of the large vortices on the lee side of the Tavan Har massif as well as the contrast in wind velocity between the Unegt and Zunnbayan basins. The three models to the right correspond to stormy days (wind speed over 30 $\left.\mathrm{m} \cdot \mathrm{s}^{-1}\right)$.

Figure 8: Interpolated sand motion map for the whole Tsagaan Els depression (a) and specifically for the Tavan Har structure (b). The black arrows indicate the direction of sand displacement (no velocity or rate indicated; color scale in degrees from north). The vectors associated with yellow dots were obtained from dunes and those associated with red dots from the mean direction measure on at least 20 sand shadow structures localized within a $100 \mathrm{~m}$ radius. The interpolation was performed using the "surface" calculation routine of the GMT Software (Smith and Wessel, 1990). 
Note that the density of data is largely controlled by the occurrence of sand in the various regions of the basin which has a direct influence on the confidence level of the interpolation.

Figure 9: a: erosion rates calculated for each surface sample following calculation options 1 or 2 . See text for details on the calculation hypothesis. b: kernel density plot of best fit erosion rates for the surface samples ( $\mathrm{n}$ is the number of erosion values considered for the calculation. See top figure for the references of the corresponding samples).

Figure 10: Comparison between erosion rates obtained from cobbles and from amalgams for the double samples. Note the 7 samples individualized by their name and having a significant difference between the erosion rate calculated on amalgam and the one calculated on cobble. See text for explanation.

Figure 11: a) Geology and topography of the Bayanshire platean 'd the western part of the main depression zone. The plateau presents two surfaces, the upr at $\mathrm{vn} r$ to the north being separated from the lower one by the North Zuunbayan fault trace. The r rid aepression is mostly filled with playas supporting ephemeral lakes. b) View from the south of the nuthern scarp of the Bayanshire plateau. The Cretaceous strata are exposed up to the last $\mathrm{m}$ et $\mathrm{r}$ before the top suggesting that the Cenozoic strata are very thin. The scarp is about $20 \mathrm{~m} \ldots$. $\mathrm{r}$. - ) View from the SW of the lower surface of the Bayanshire plateau. The cars in the circle g1 the scale. d) Sediment log of the three profiles (see text for a complete description).

Figure 12: ${ }^{10} \mathrm{Be}$ and ${ }^{26} \mathrm{Al}$ concentratj^ns $\neg \mathrm{d}^{26} \mathrm{Al} /{ }^{10} \mathrm{Be}$ ratios versus depth in the three sampled pits. Black dots are samples from the lih. ied lower sedimentary unit, triangles are surface samples and dots are samples coming from a li: re sandy layer (so called "active" layer) on top of the indurated unit and below the surface 1 a. 'el composed of small pebbles. Dashed line is the best fit model obtained for the lithified $u_{1 .}{ }^{t}$ ( vilack dots).

Figure 13: Following Siame et al (2004) and Wolkowinsky and Granger (2004), these contour plots aim at determining the uncertainties associated to the erosion and exposure ages. Black dots are the minimum $\chi^{2}$ corresponding to the best erosion and exposure age estimates. Black arrows point to either maximum or minimum erosion rates (vertical) or exposure ages (horizontal) associated to those best estimates. These uncertainties are determined using the minimum $\chi^{2}$ value plus one (Wolkowinsky and Granger, 2004).

Figure 14: Model of wind flow and wind erosion patterns around the Tavan Har massif. The frontal depression corresponds to an area combining a maximum velocity of the wind flow arriving into the Unegt Basin and retrograding erosion from the two ends of the Tavan Har massif. The strong 
acceleration of the wind flow around the extremities of the massif associated to the down-flow of the vortices developing in the lee zone increases the shear stress and generates strong erosion in the secondary depressions. The grey areas mark the position of the low velocity zones behind the Mandakh-Saykhandulaan ridge and the Tavan Har massif. Cross sections are showing the lithology of the substratum as well as the wind flow pattern.

Figure 15: Evolution of the ${ }^{26} \mathrm{Al} /{ }^{10} \mathrm{Be}$ at a given depth after a shift of erosion from 3 to $10 \mathrm{~m} / \mathrm{Ma}$. Values near the dots are the time span (exposure time at surface) since the shift. In that peculiar case, it takes more than $10 \mathrm{Ma}$ to reach the new equilibrium state. An "apparent" burial age up to $1 \mathrm{Ma}$ can be determined. 


\section{Figure 1}
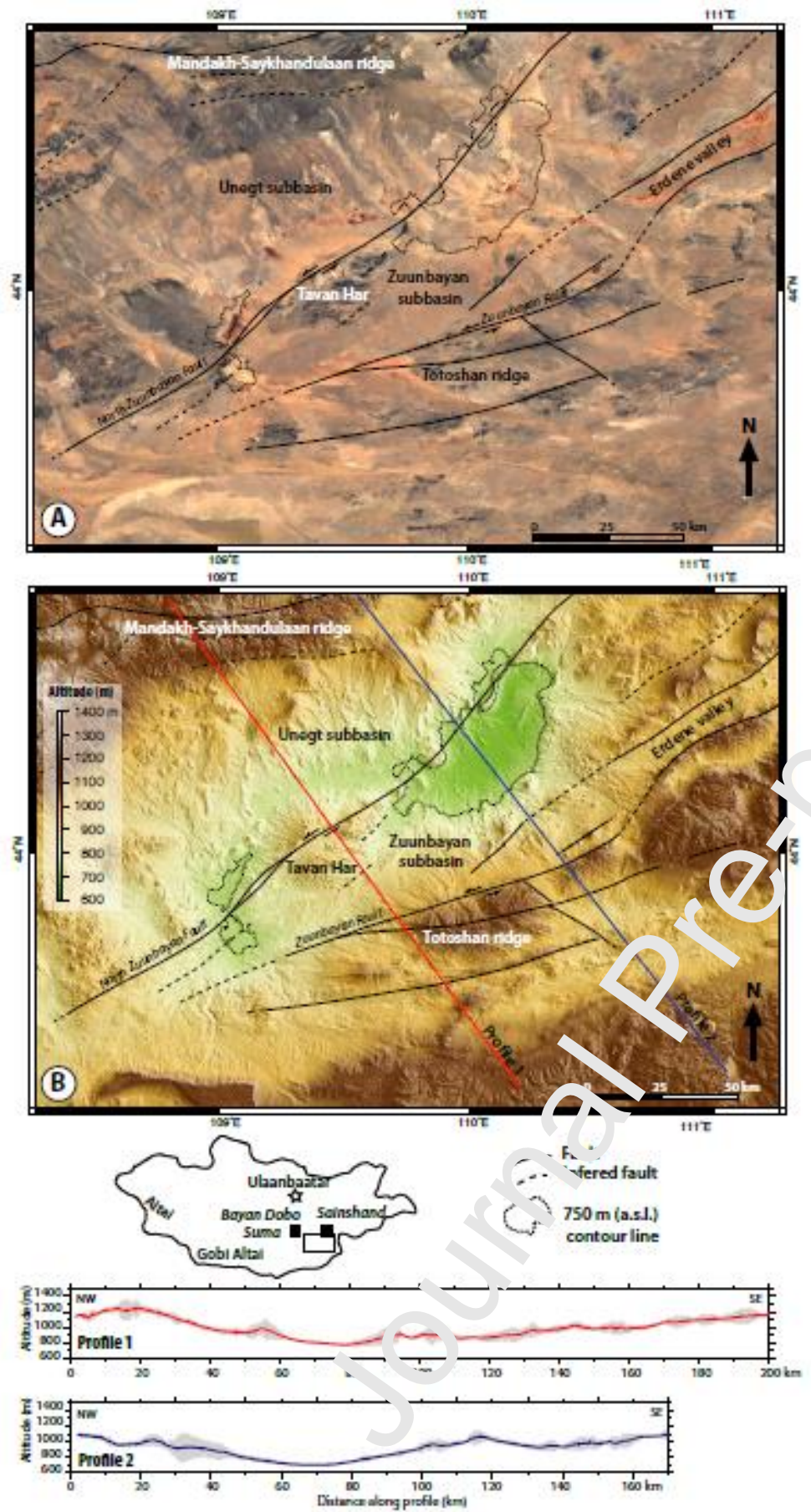
Figure 2

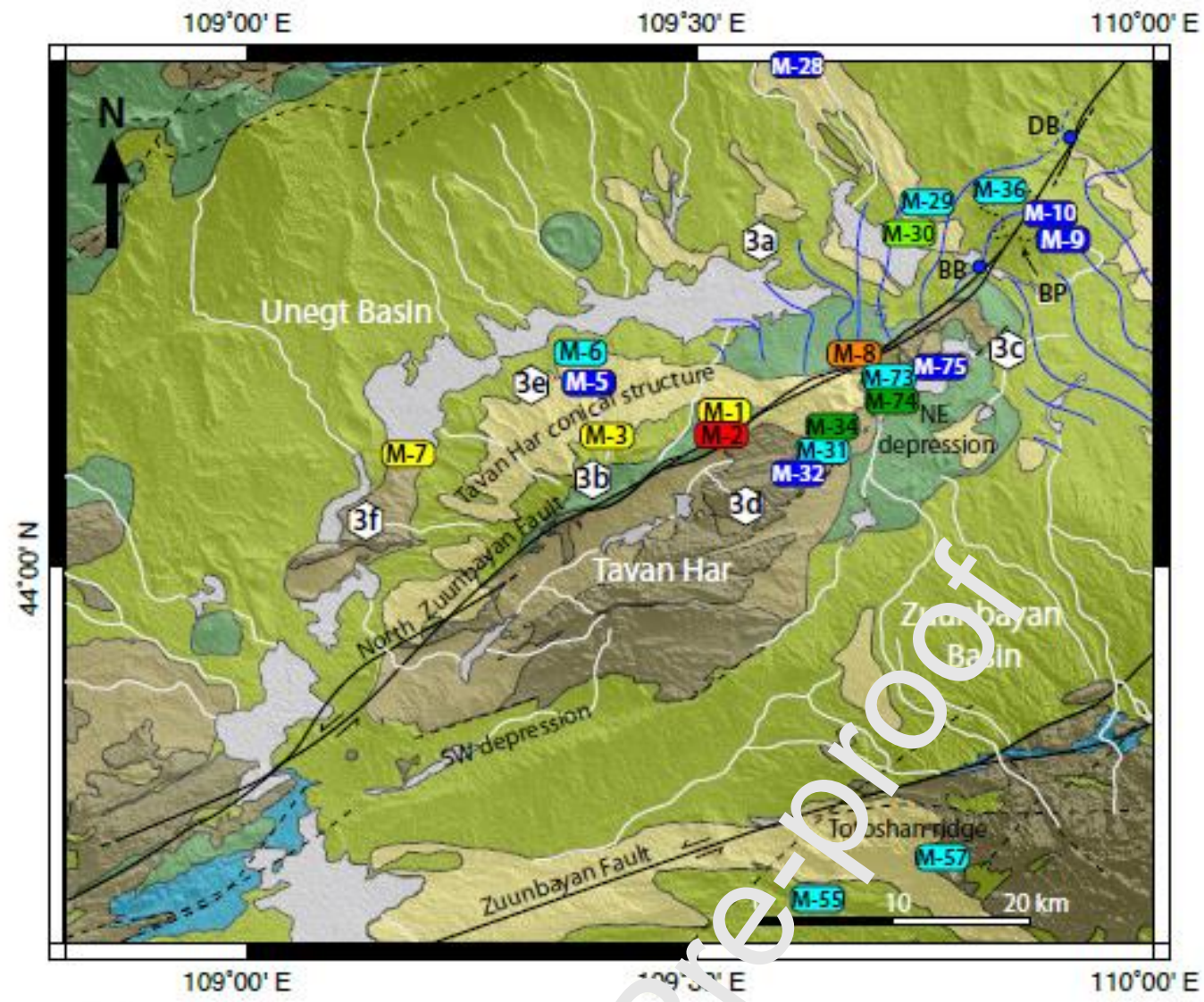

Playas/Ephemeral lakes $\}$ Quaternary

Upper Crecateous sediments

Lower Cretaceous sediments

Jurassic sediments

Colluvion on basement

Metamorphic basement

(M-1) Samples for cosmogenic isotope ath "vsis

(32) Position of field photographs c. Figv e 3

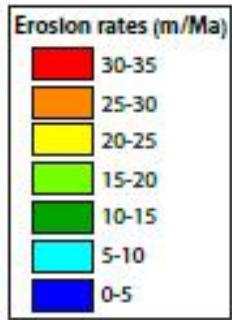

-- Faults and inferred fault

- Piezometric lines 


\section{Figure 3}
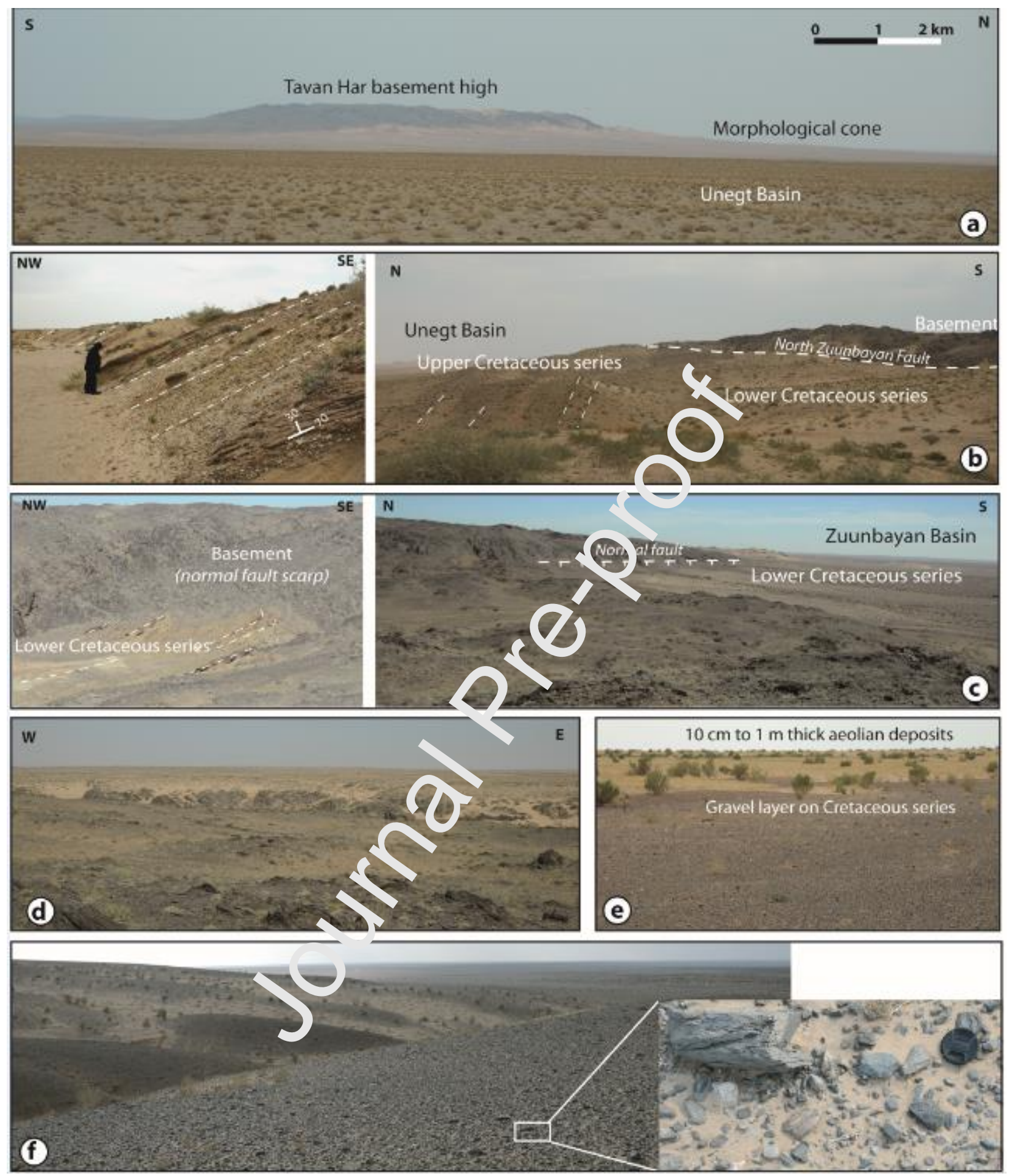
Figure 4

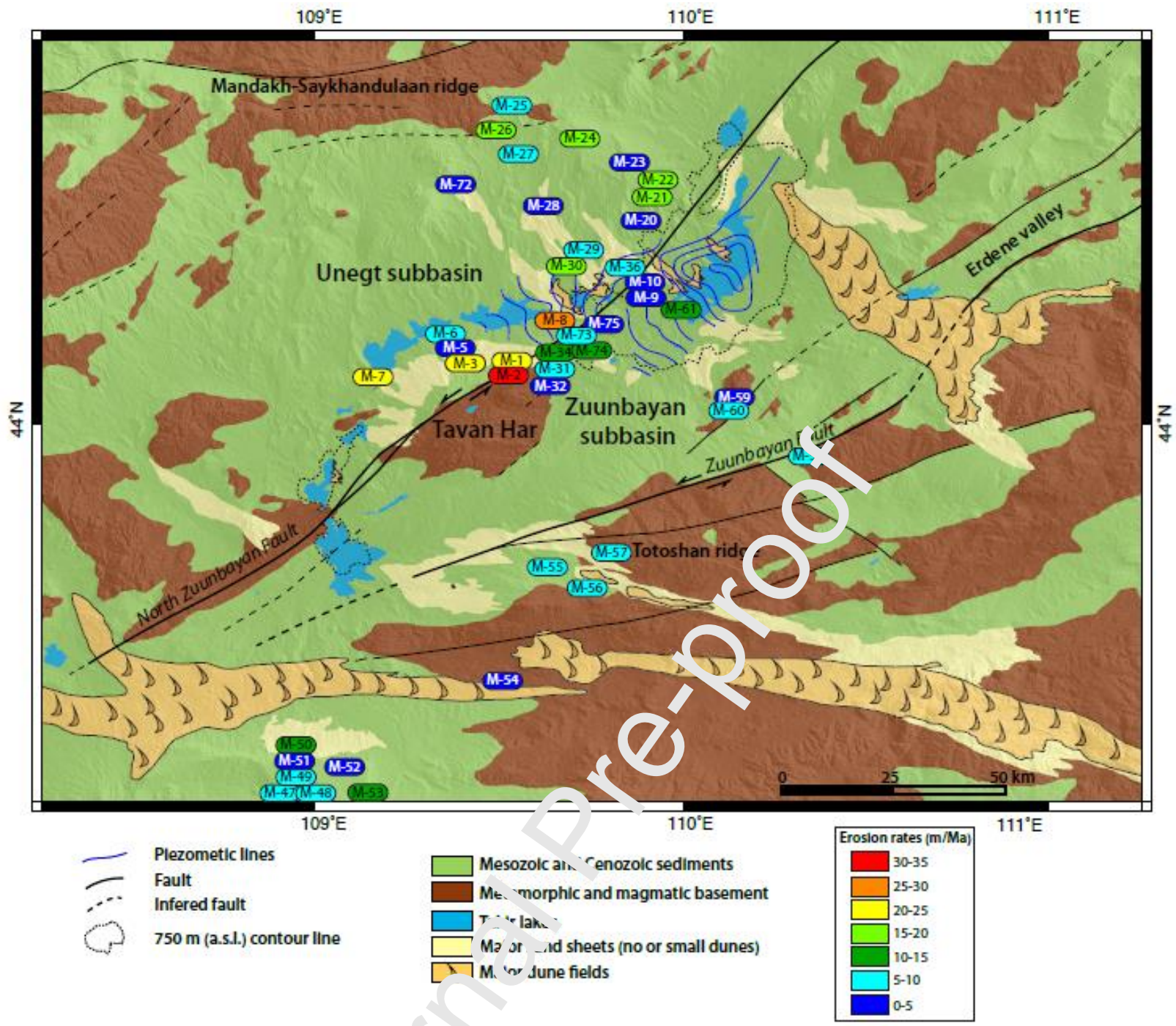


Figure 5
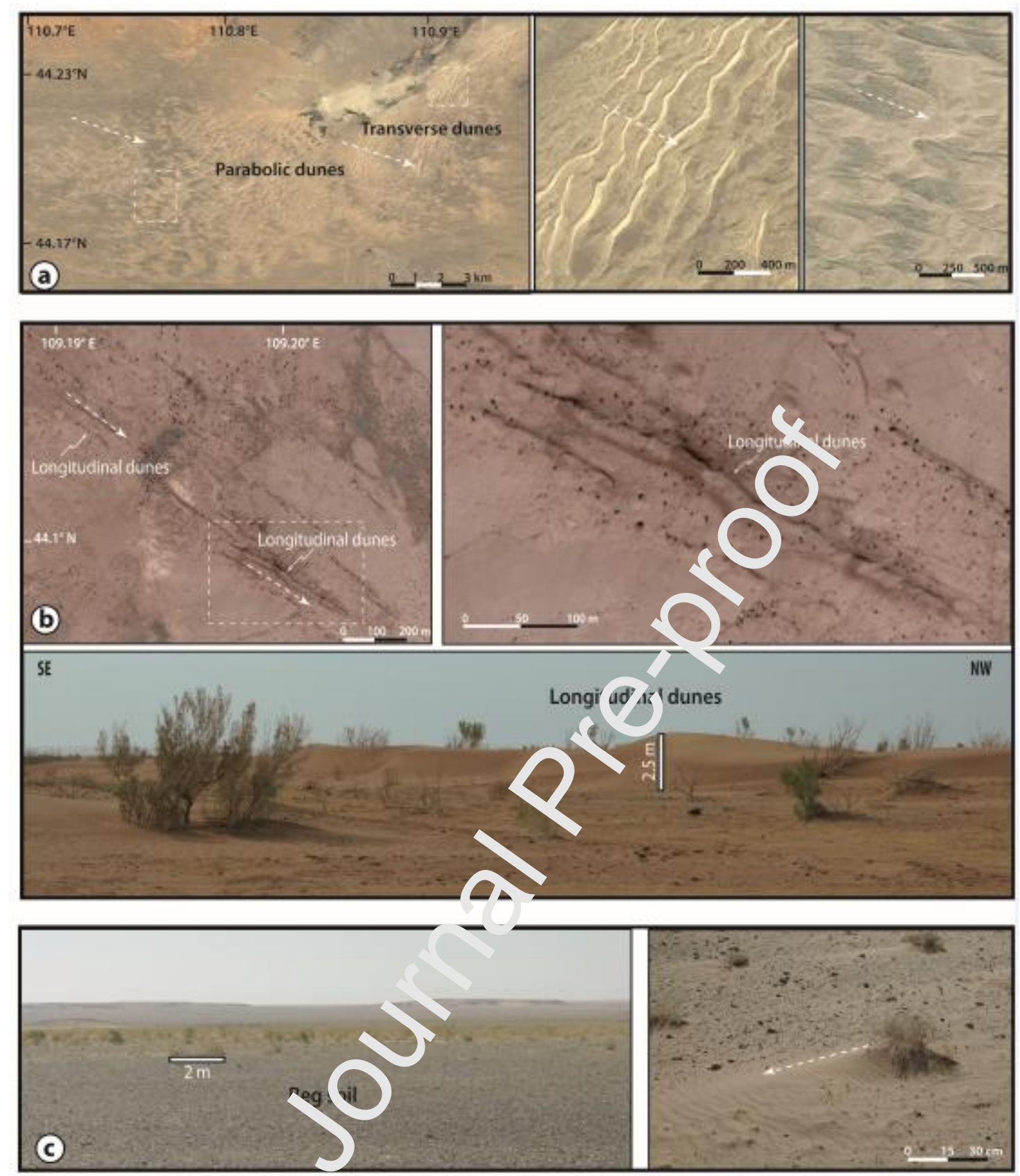
Figure 6
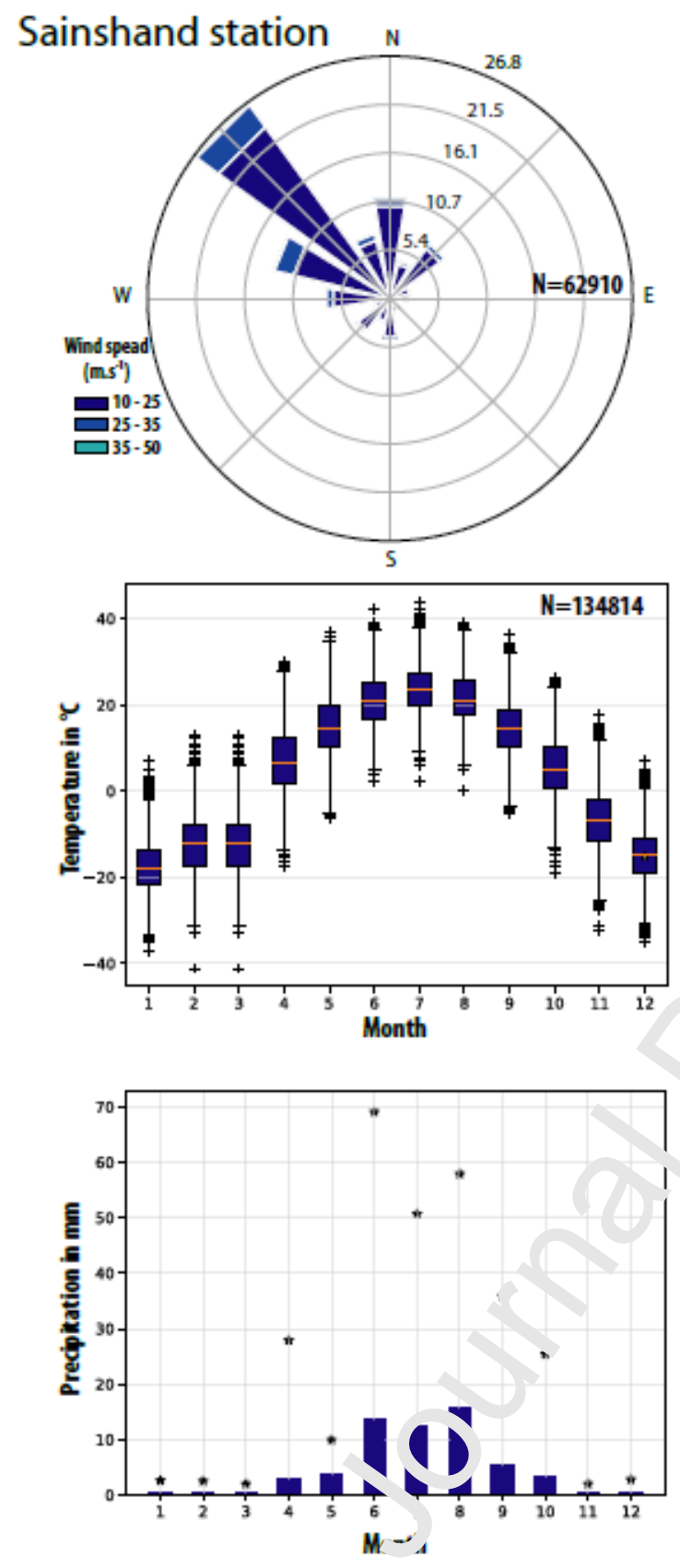
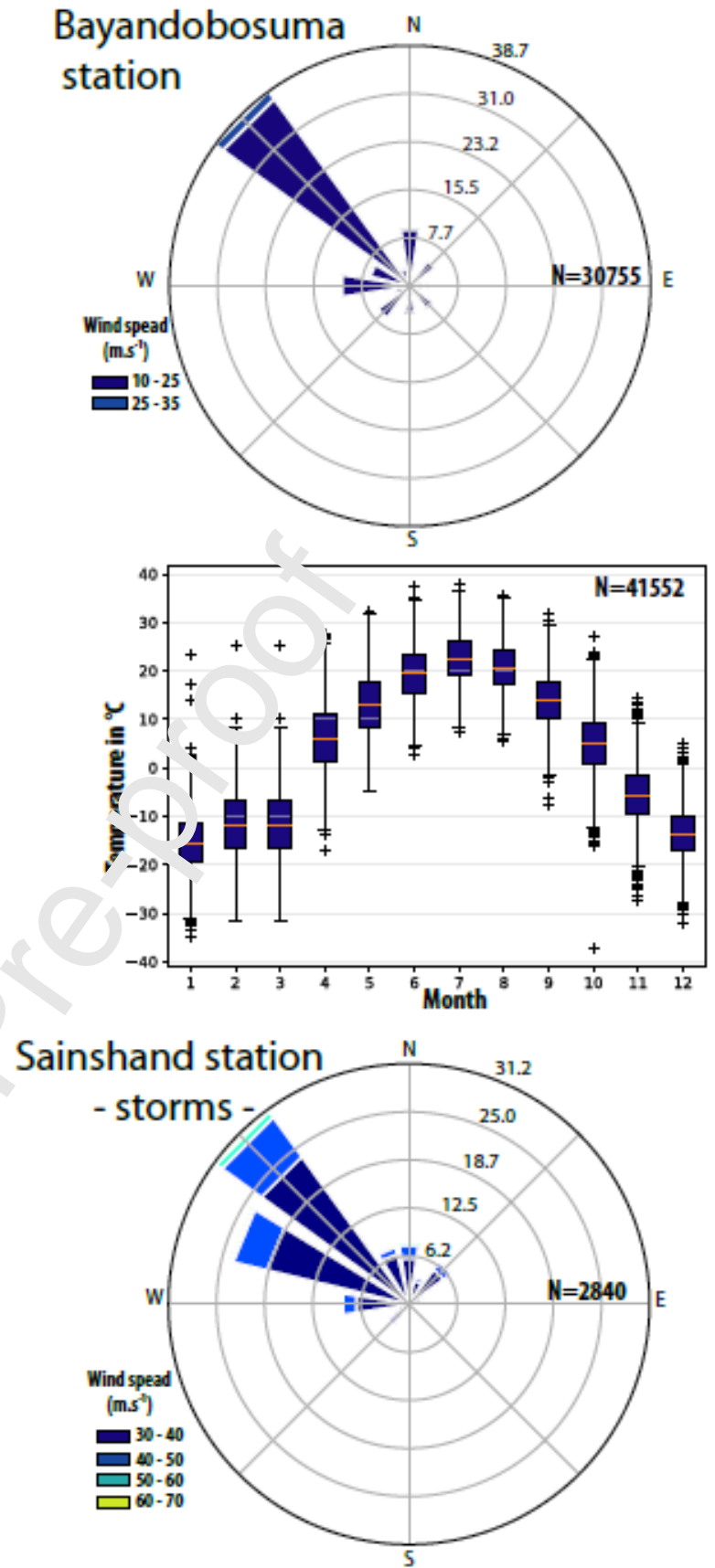
Figure 7

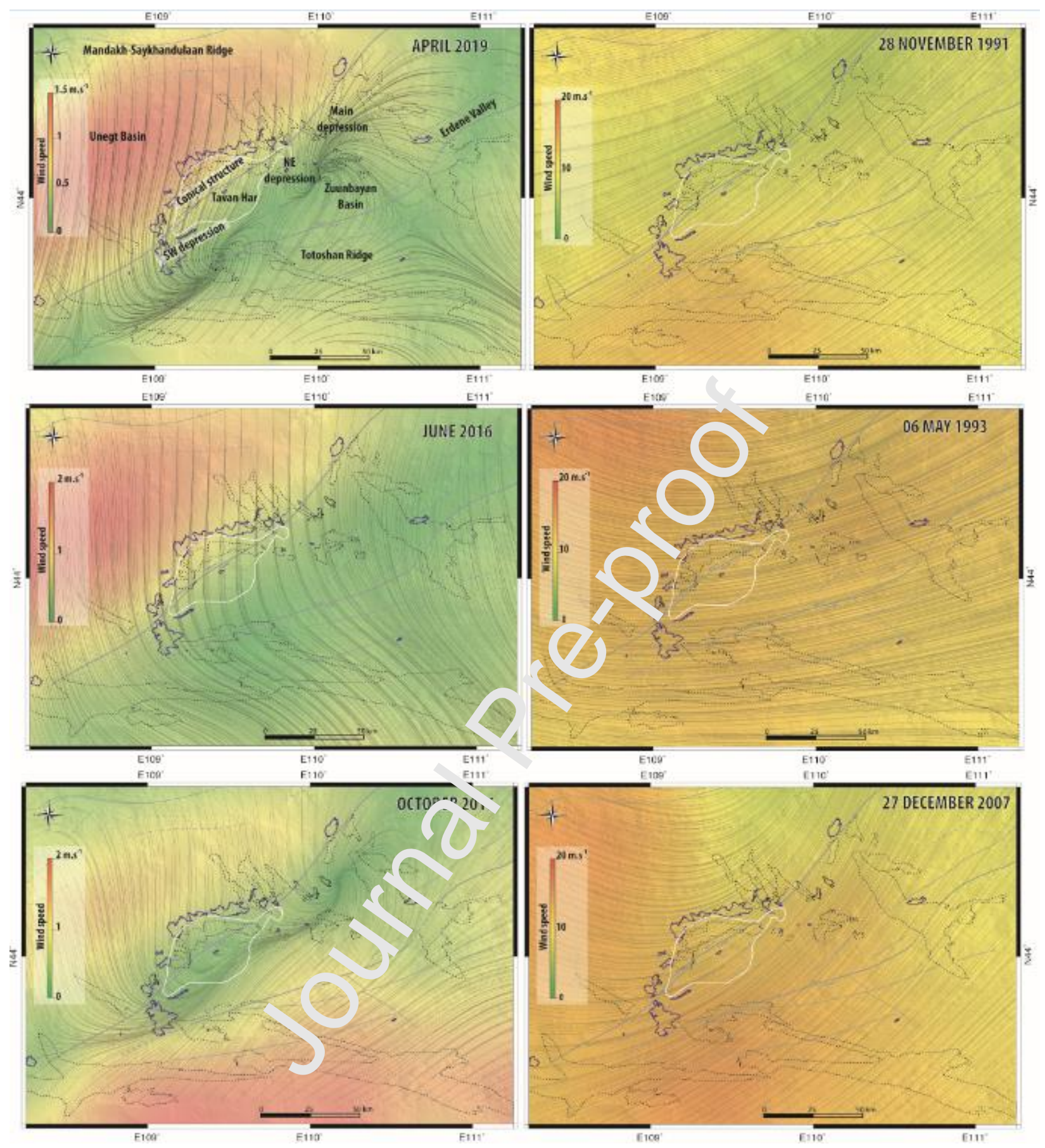


Figure 8
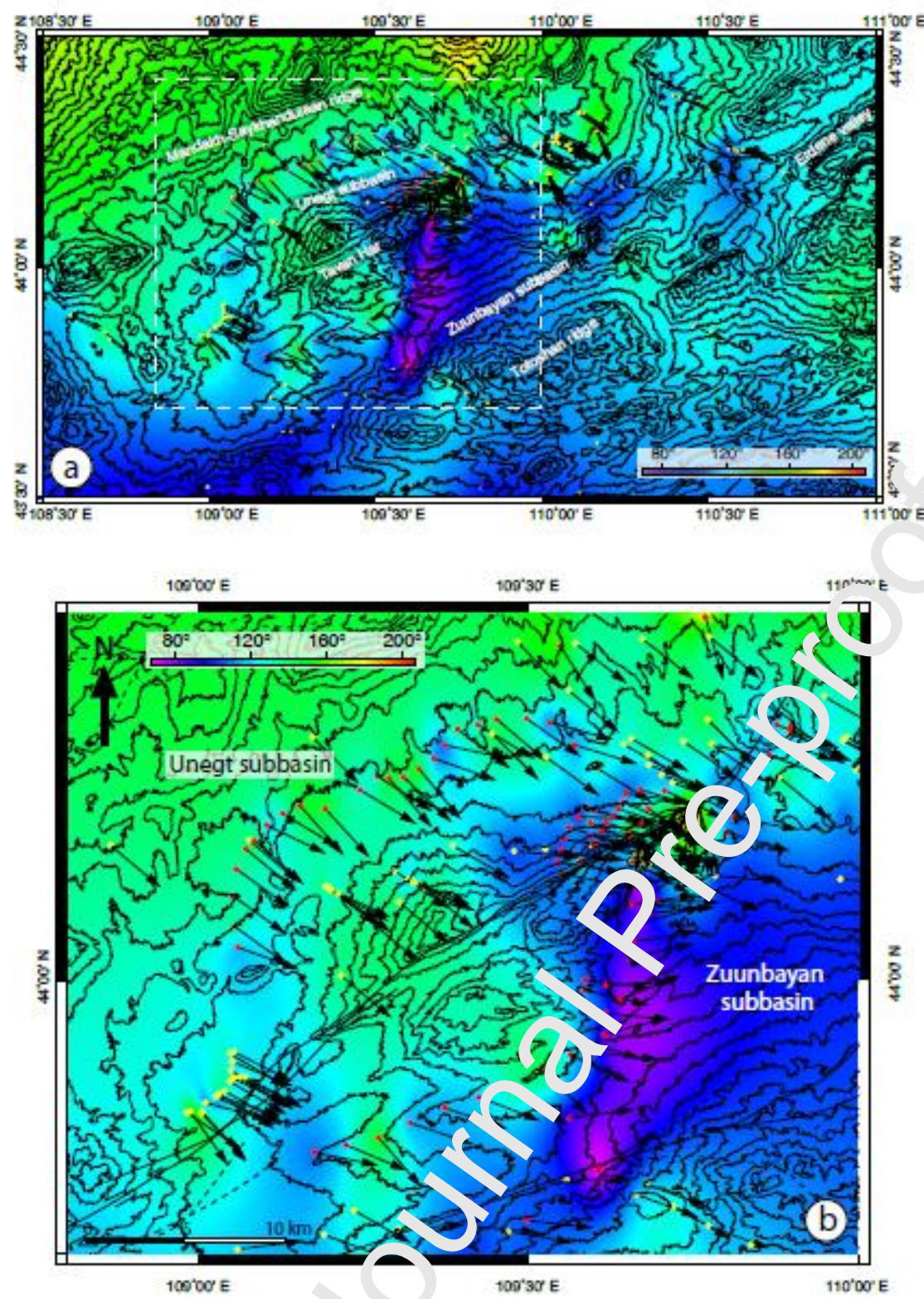
Figure 9
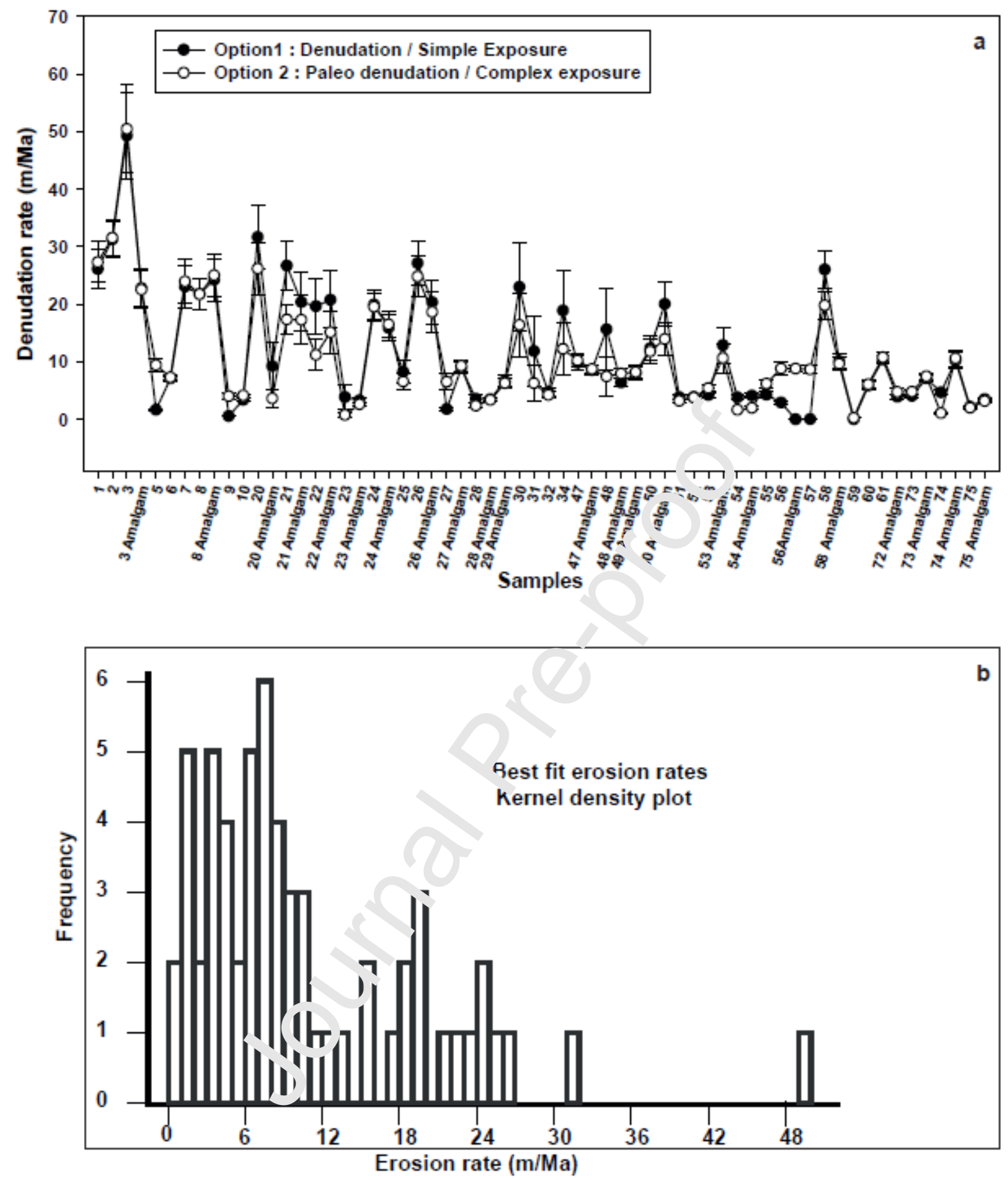
Figure 10

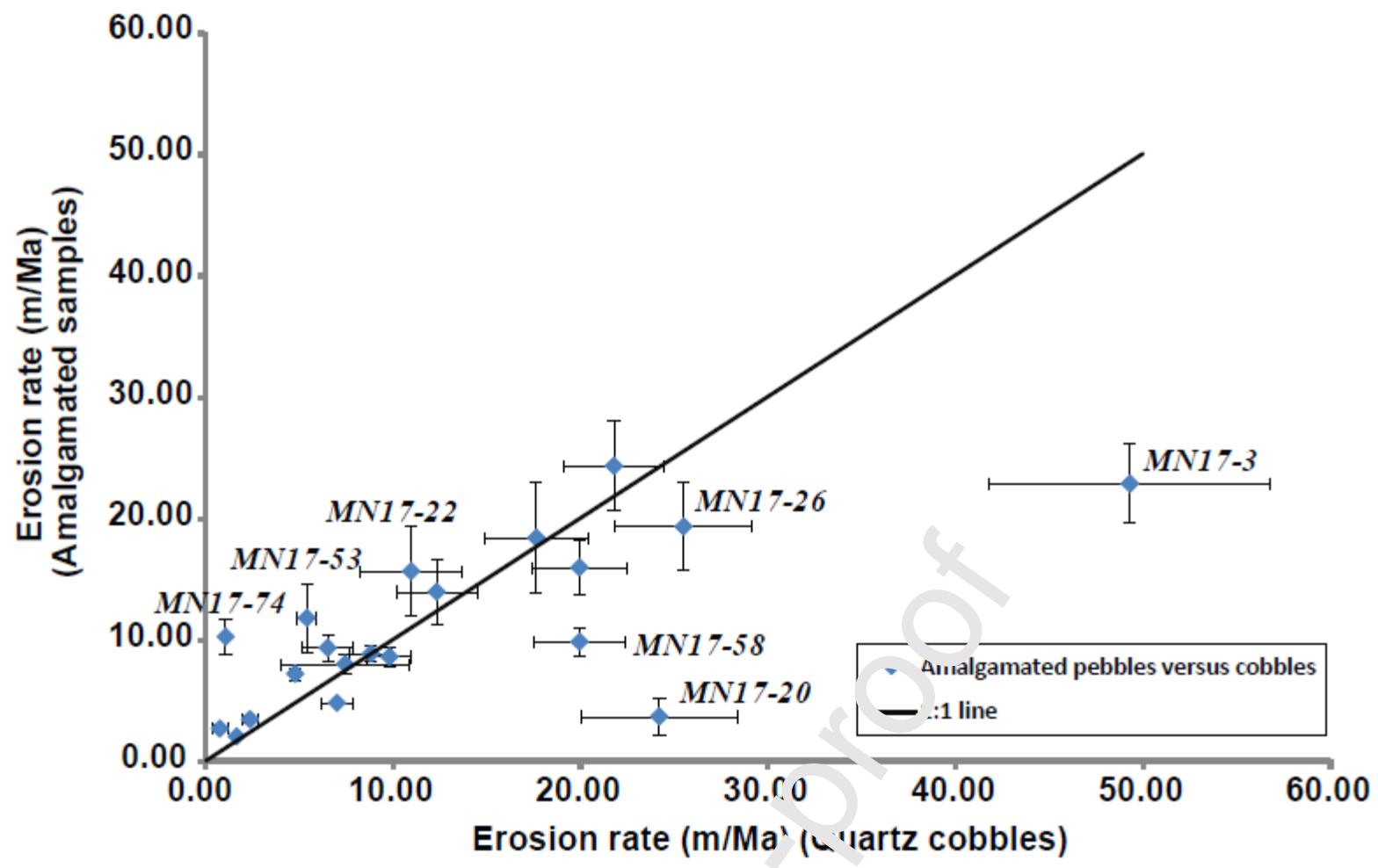


Figure 11
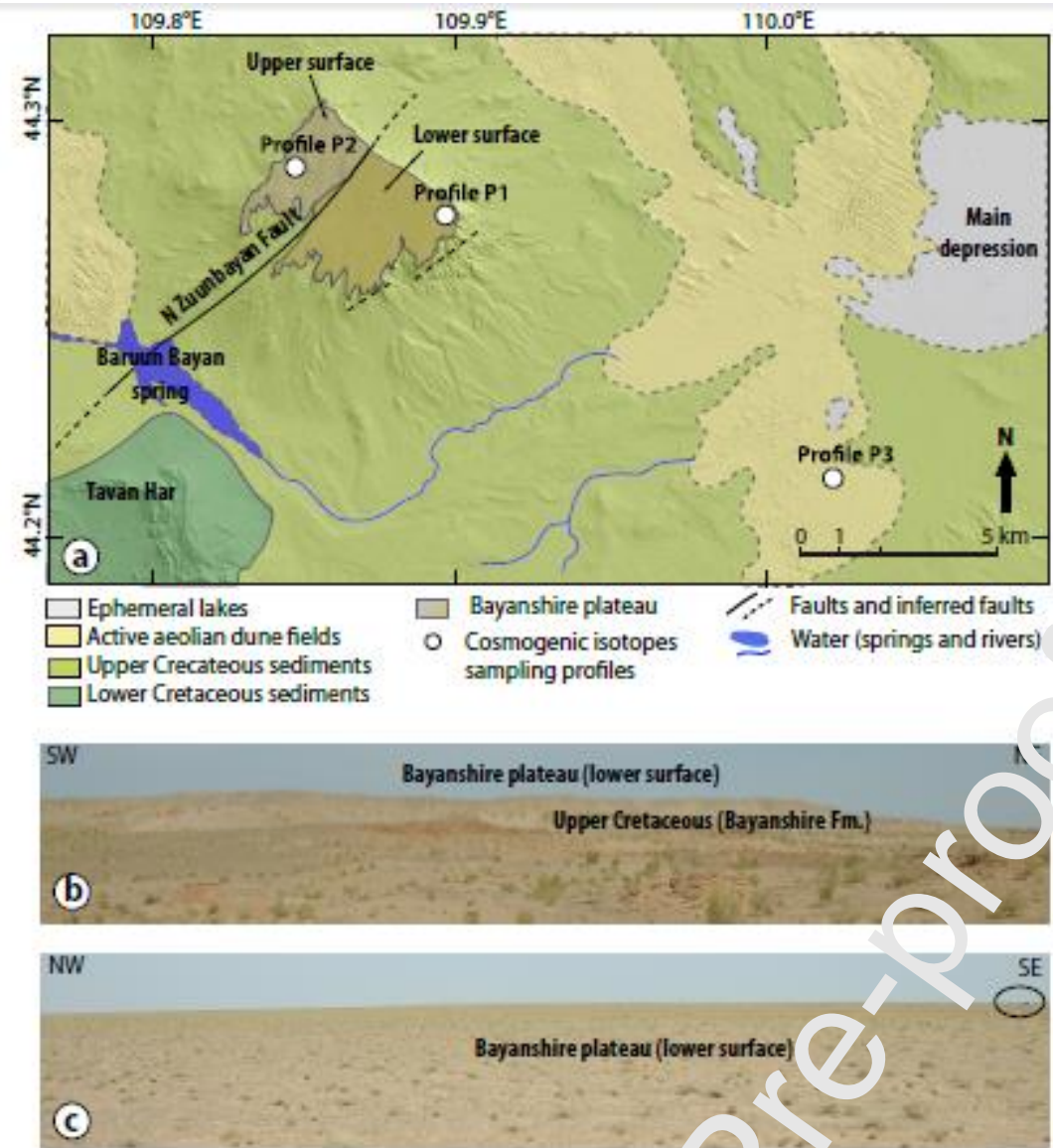

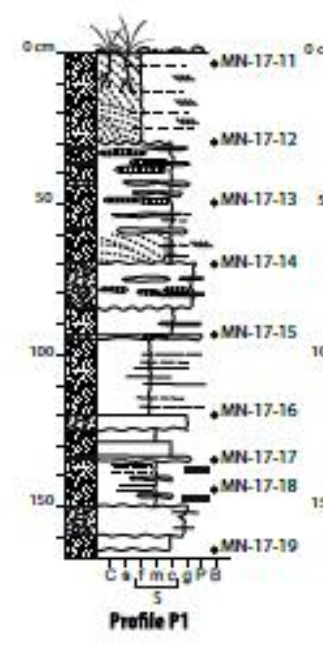

(d)

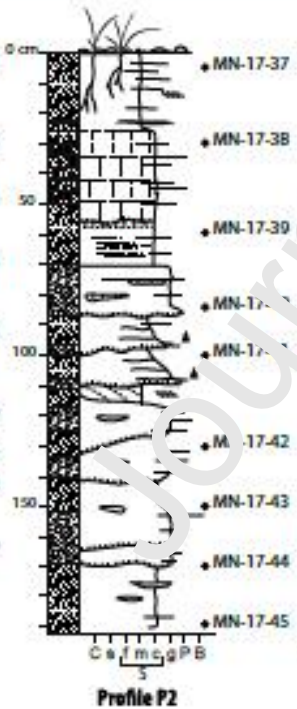

Profile P2
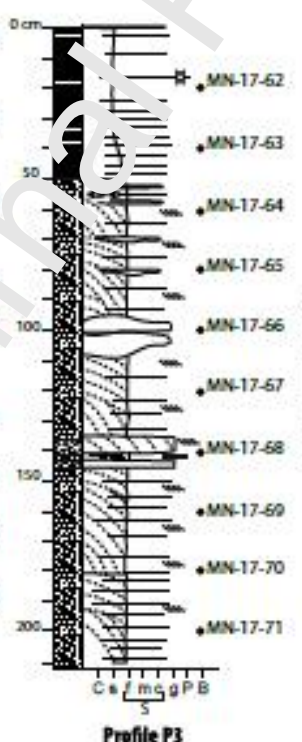

\section{CAPTION}

* Mud cracks

4 Roots

- Grain sorting

- Oxidized crust / layer

- 3D megaripples

- Horizontal lamination

- Carbonated nodules

- Carbonated lenses

- Mv-17-11 Samples

Sandstone

Silt

미 Carbonate cement

[ask Conglomerate 
Figure 12

\section{Profile 1}
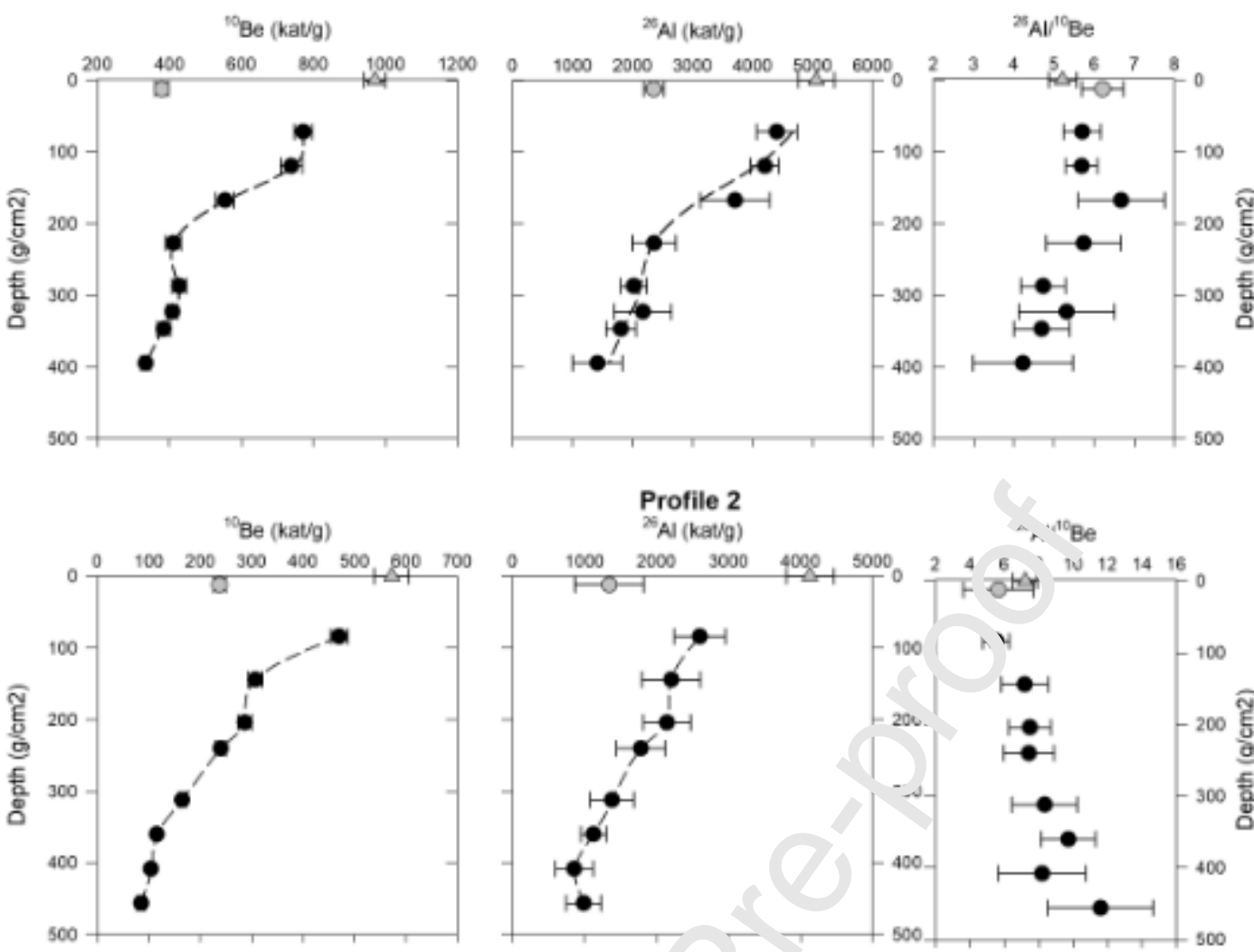

Pr. Fle

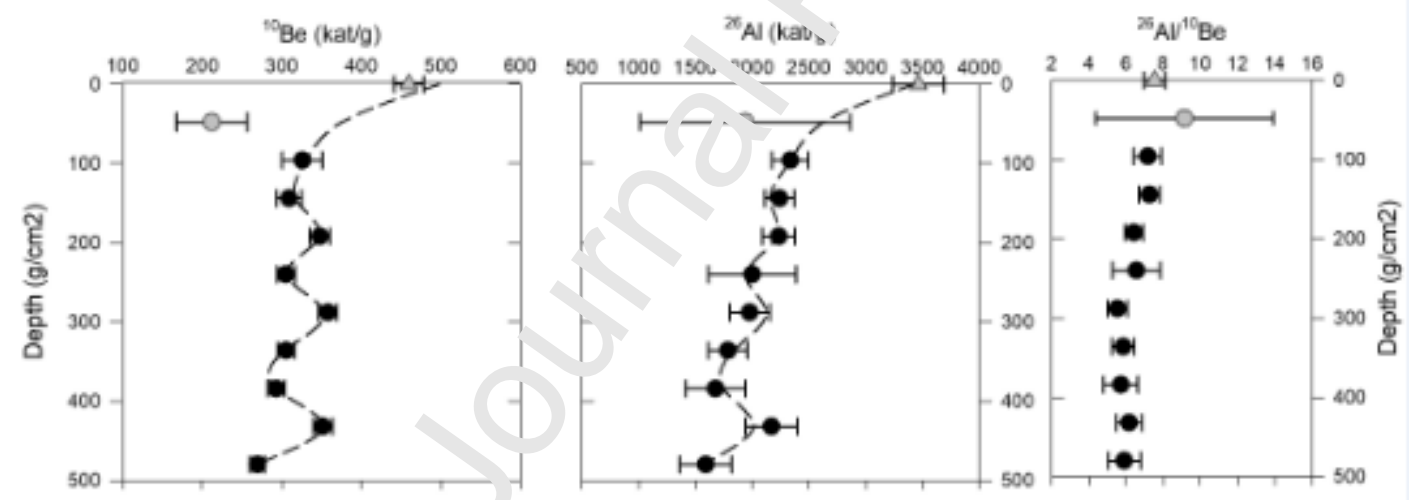
- $10 \mathrm{Be}$ or $26 \mathrm{Al}$
Surface sample
Active layer in depth profile
Best fit based on 
Figure 13
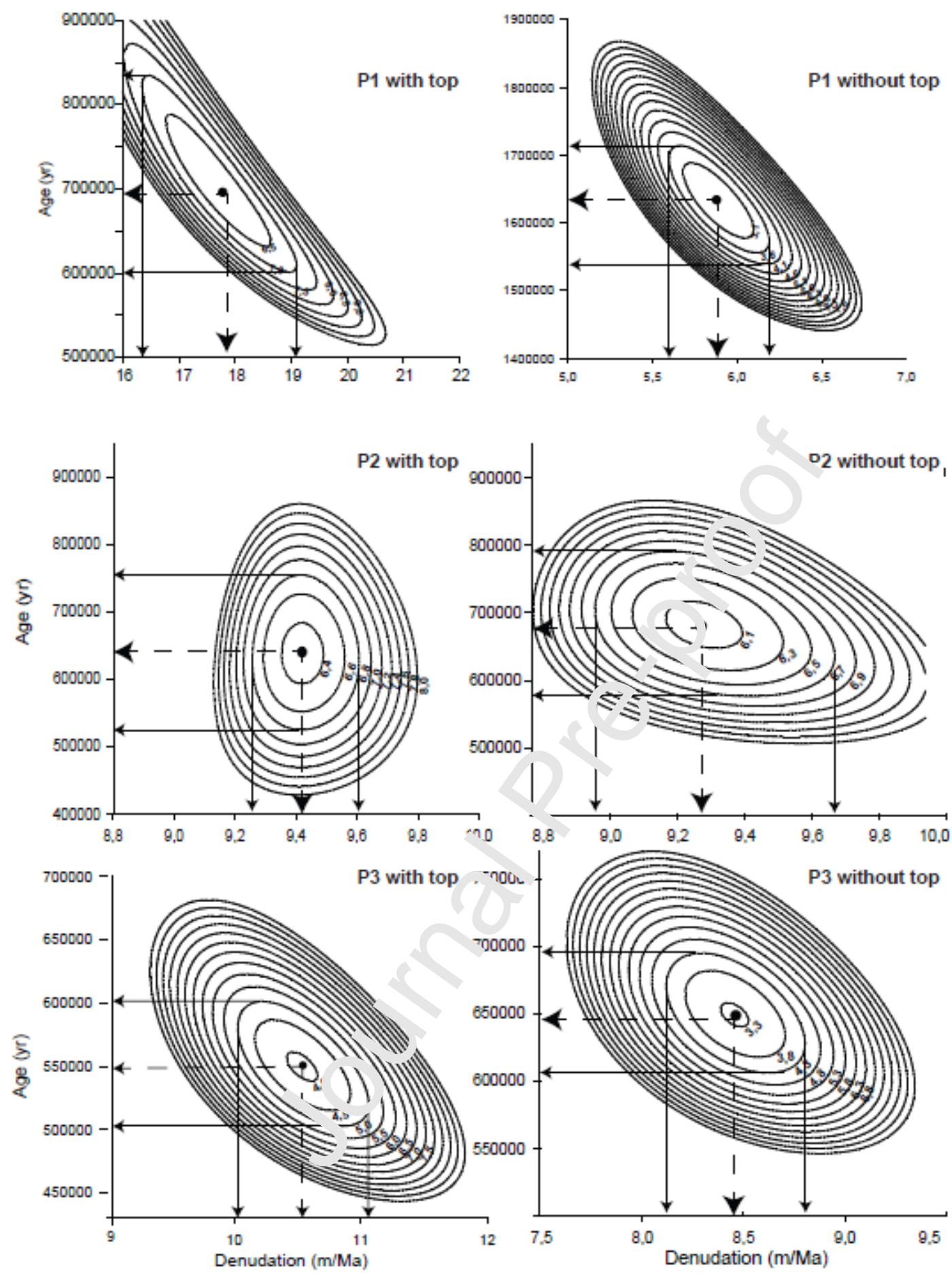
Figure 14

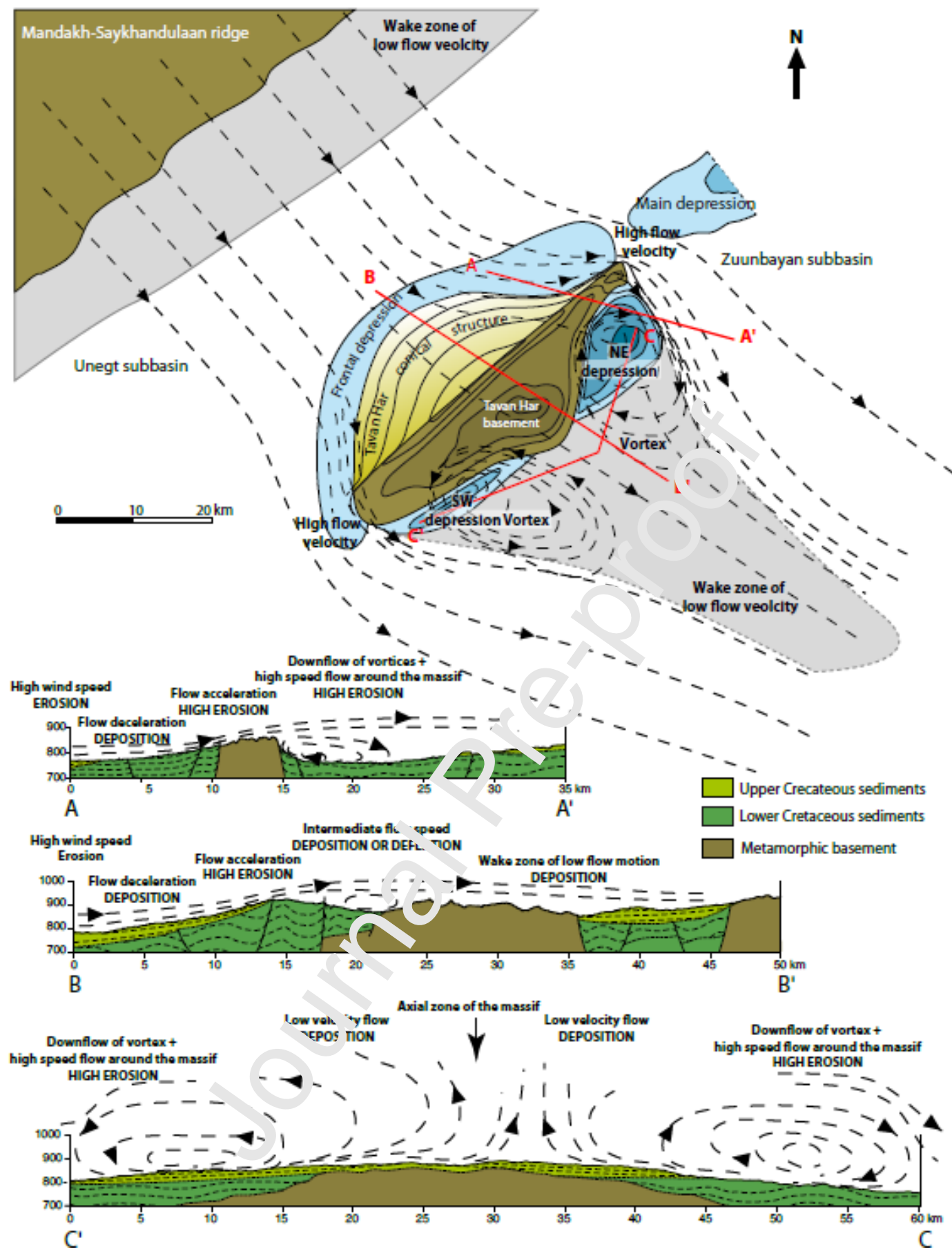


Figure 15

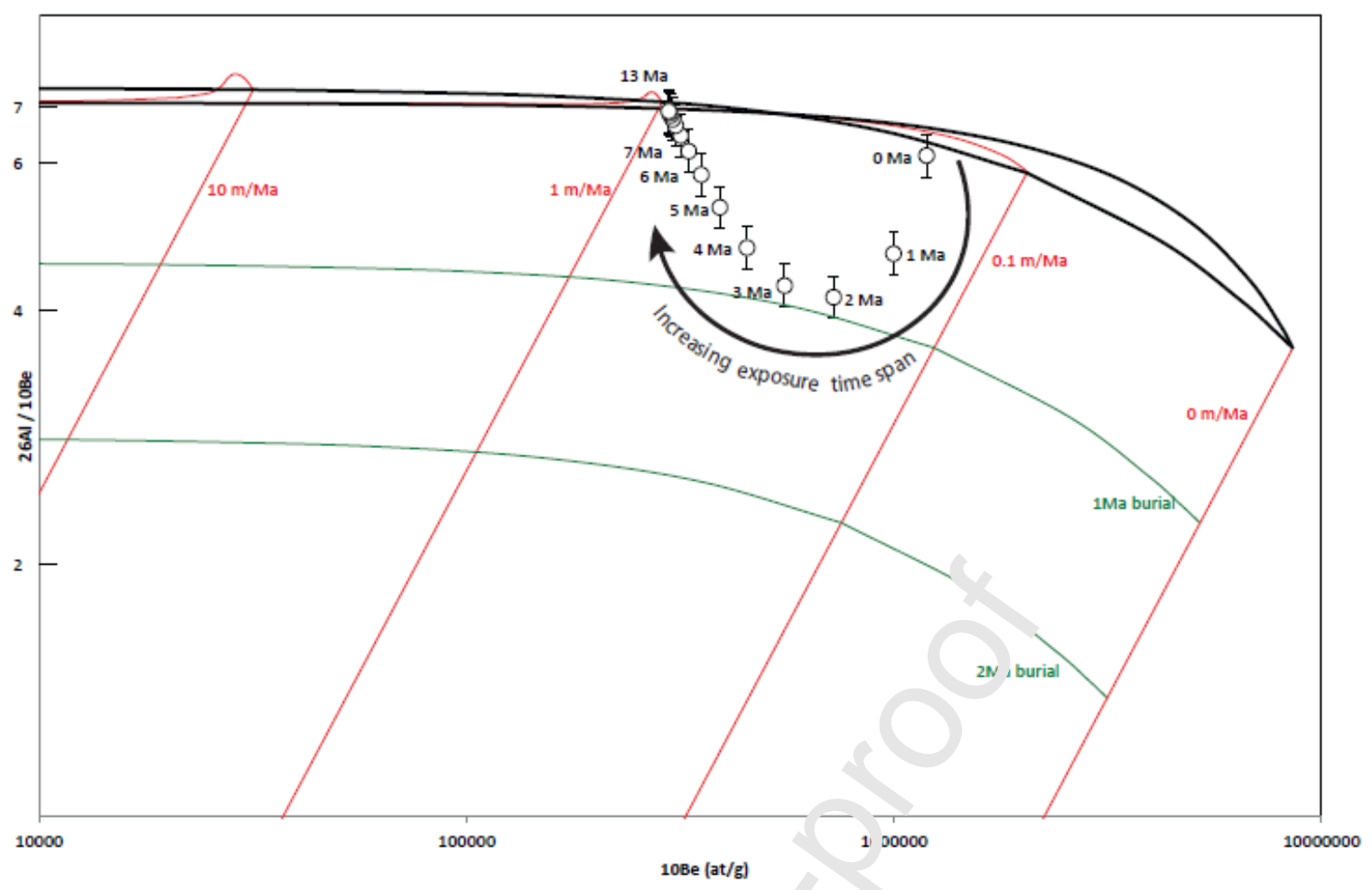




\section{Declaration of interests}

$X$ The authors declare that they have no known competing financial interests or personal relationships that could have appeared to influence the work reported in this paper.

$\square$ The authors declare the following financial interests/personal relationships which may be considered as potential competing interests: 


\section{Highlights}

- Non-erodible obstacles in semi-arid sedimentary basins focus deflation

- Enhanced deflation zones form sub-depocenters controlling local drainage systems

- Fluvial - aeolian interactions are described in a conceptual erosion model

- Cosmogenic $10 \mathrm{Be}$ and $26 \mathrm{Al}$ analysis indicate generally low erosion rates in Gobi desert

- Erosion rates increased in the Gobi region after the Middle-Pleistocene transition 